\title{
Orígenes del control de los proyectos de obras públicas por la Academia de San Fernando (1768-1777)
}

\author{
José Enrique García Melero ${ }^{1}$
}

\begin{abstract}
RESUMEN
Trata sobre los orígenes de la censura de obras públicas en España por la Academia madrileña entre los años 1768 y 1777. Se estudian a través de la documentación hallada en su

Archivo y la bibliografía paralela complementaria. Se hallan en una serie de representaciones de los académicos al Rey Carlos III, fechadas en los años 1768 y 1777 , sobre la actividad gremial.

Entonces se criticaba el empleo del estilo barroco por los gremios. La crítica se centró, sobre todo, en el retablo. En su realización participaban tanto los maestros gremiales como los arquitectos, escultores y pintores académicos. En este artículo se destaca la influencia indirecta de la Academia de San Carlos de Valencia en las reales órdenes de 1777. Con ellas se cumplió el ideal político de centralización de las obras públicas en

la Corte, tan del agrado de los reyes españoles de la llustración. En la política llevada a cabo por la Academia madrileña hay que destacar varios
\end{abstract}

\begin{abstract}
This article treats about the origins of the censure of public works in Spain done by the Madrilenian Academy from 1786 to 1777. The studies done in this article are based on the documentation found in the own Academy's Archive and in other complementary sources. We can find these origins in a serie of requests made by the academics to the king Carlos III and that are dated between the years 1768 and 1777, about the guild activity. By this time it was criticised the use of the Baroque style by the guilds. The critic was basically focused in the retable. Its realization not only was a task of the guild masters but also architects, painters and sculptors take part. In this work we point out the indirect influence of the San Carlos Academy, from Valencia, in the royal orders made in 1777. This orders caused the fulfilment of the politic ideal of centralising the public woks in the court, as was desired by the Spaniard kings in the llustration period. Some aspects can be remarked about the politic actions carried out by the Madrilenian Academy:
\end{abstract}

1 Departamento de Historia del Arte de la UNED. 
aspectos: la pugna de los artistas académicos contra los gremiales para hacerse con los encargos de las obras; la oposición entre el estilo barroco y el neoclasicismo; la crítica al despilfarro de los artistas gremiales y el deseo de imponer la economía en las obras de arte; la lucha de la Academia contra el

Consejo de Castilla, que deseaba seguir con el control de las obras públicas. the fight started by the academical artists against the guilds as a way of obtaining the control of the public works; the oposition between the Baroque style and the Neoclassicism; the critic against the wasting made by the guild artists and the desire of imposing some mechanisms to control this waste; the fight of the Academy against the Castilla Counsil, which wanted to follow with the public works control.

La creación de la Comisión de arquitectura de la Academia madrileña en 1786 es, sin duda, uno de los grandes hitos para conocer la teoría y la práctica constructivas españolas - y aún urbanística- del período comprendido entre 1786 y 1846. En este último año cambió su denominación por el de Sección de arquitectura y como tal siguió desempeñando similares funciones hasta finales del siglo XIX, aunque su labor fuera devaluándose poco a poco con el transcurso del tiempo. En el cambio de denominación quizá sea posible percibir un paralelo tanto cronológico como formal con la creación de la nueva Escuela Especial de Arquitectura, fundada en 1844 en Madrid, que desposeía al instituto de la ya secular función docente de este arte práctico. Ello se venía prediciendo, por el propio viceprotector Bernardo de Iriarte, desde los debates de 1793 entre los arquitectos, presididos por Juan de Villanueva, y los matemáticos Varas y Bails en la Academia.

Se recordará aquí que la función fundamental de esta junta, creada por real orden al margen de los Estatutos de la Academia de San Fernando, fue establecer el control de las principales obras públicas, que se realizaban en España, desde una junta periódica extraordinaria de arquitectos de ese instituto. Se deseaba de esta forma garantizar su calidad e imponer el nuevo clasicismo, con todas sus variaciones dialectales experimentadas a lo largo del tiempo, como lenguaje de la nueva dinastía de los Borbones. A ello hay que añadir que tal servicio fue un instrumento político necesario para garantizar el trabajo de los arquitectos salidos de la Academia frente a los practicantes gremiales, que seguían aferrados al gusto barroco ornamental. Obedeció, así pues, a las directrices absolutistas y centralistas de Carlos III, promovidas en gran parte por el conde de Floridablanca.

El estudio de esta Comisión resulta, así pues, totalmente imprescindible para conocer la teoría y la práctica constructivas españolas desde 1777 
hasta, en especial, finales del tercer cuarto del siglo XIX. A través de esta labor de censura de las obras públicas tanto civiles como eclesiásticas, cuyos dictámenes de hallan en los libros de actas de este servicio, es posible no sólo establecer un seguimiento de las principales realizaciones arquitectónicas en España durante este largo período histórico, sino también advertir los cambios de gusto y las variaciones en las concepciones tipológicas y sus familias de modelos. Resulta, pues, un elemento clave y esencial de investigación junto con el complementario de las distintas pruebas de exámenes, conservadas en el Archivo de este instituto, a las que se sometían a los diferentes profesionales de la Arquitectura en la Academia: académicos de este arte, arquitectos, maestros arquitectos y maestros de obras.

En este artículo se pretende establecer un estado de la cuestión, basado en el estudio de documentos y libros de actas de juntas del Archivo de la Academia, con la consulta de la bibliografía paralela, sobre los orígenes entre 1768 y 1786 de la llamada Comisión de arquitectura. Su creación estuvo precedida por una serie importante de representaciones enviadas al Rey Carlos III, que le motivaron, no sin debates previos, a decretar tal disposición fundacional. Redactadas primero por los artistas, unas veces de forma espontánea y otras, la mayoría de las veces, promovidos por las juntas particulares académicas, fueron asumidas plenamente por los consiliarios. Por lo general, éstos encargaban a aquéllos, desposeídos de toda capacidad de decisión, la redacción de informes y memorias facultativas sobre sus respectivos artes. El secretario de la Academia, una vez discutidos y aprobados por la junta particular correspondiente, daba forma a tales escritos con la finalidad de presentarlos al Rey a través del Protector, el primer Secretario de Estado, para su realización en disposiciones legislativas concretas, si su finalidad se juzgaba políticamente conveniente. Carlos III reflejó sus contenidos bastante literalmente en varias reales ordenes.

Las representaciones académicas al Rey se ocupaban de asuntos en apariencia bastante diversos entre sí, pero siempre complementarios. Su finalidad era conseguir un conjunto de objetivos muy claros y precisos necesarios para aumentar y mejorar el poder y la actividad de la Academia. En ellas fueron analizados aspectos tan importantes como: la formación más adecuada de los arquitectos, el método a emplear en los distintos exámenes para otorgar los diversos grados de la Academia, el control efectivo de los gremios, la centralización y censura de cuantos edificios públicos se construían en España al margen del Consejo, la necesidad de que los arquitectos responsables de tales obras fueran exclusivamente los aprobados por este organismo... 
El fin perseguido por este conjunto de disposiciones, que incluían al mismo tiempo medidas políticas y didácticas, era muy evidente: aumentar el poder efectivo del Rey y de su Academia, a la que únicamente competiría desde entonces el control de las Bellas Artes, y favorecer la penetración del nuevo clasicismo en el país como el lenguaje artístico oficial de la nueva dinastía. Con todo ello se conseguía, además, centralizar la enseñanza y la práctica arquitectónica de la nación en la Corte. Se realizaba de esta forma una parte más - no era un proceso único sino diverso- del programa político de la Monarquía borbónica basado en el absolutismo regio y el centralismo político-administrativo. También hay que tener en consideración que durante la llustración la Academia formaba parte importante del complejo entramado pedagógico del Reino en un momento histórico, durante el cual se estaba reformando todo el sistema educativo español, reforma propiciada por la expulsión de los jesuitas en 1767; es decir, un año antes de la primera representación que aquí se estudiará. La reforma se basaba en la universalidad y regularidad de los estudios impartidos frente a las particularidad y diversidad de los estudios heredados de la época de los Austrias.

Resulta muy significativo que el origen de la creación de la Comisión de arquitectura de la Academia se halle en realidad en la critica entablada en los años finales de la década de los sesenta principalmente contra los escultores gremiales, en especial contra los autodenominados arquitectos adornistas o retablistas. Estos artistas eran considerados en cierta forma no sólo como los principales responsables de los desarreglos de la escultura, en calidad de competencia propia y campo específico de su actividad, sino también de la misma arquitectura, que por los excesos ornamentales se había hecho casi escultórica. Además, el objeto principal de tales polémicas tenía como marco principal el retablo, lugar de encuentro obligado entre los escultores, pintores y arquitectos, así como campo específico de la actividad de otros artistas menores o artesanos sobre los cuales los gremios ejercían entonces toda su presión. A ello hay que añadir los problemas de competencias habidos entre los arquitectos y los escultores por atribuirse el diseño del proyecto del retablo en calidad de algo exclusivo de su actividad artística teórica. Aquéllos consideraban tal labor como específica función arquitectónica y relegaban tan sólo a éstos a ejecutar materialmente la idea previa.

Hay un aspecto importante que indicar aquí: el papel determinante, pero casi siempre un poco entre sombras, que la Real Academia de San Carlos de Valencia desempeñó, como instituto filial de la madrileña, en la redacción de estas representaciones al Rey. Los problemas suscitados en ella entre los retablistas y adornistas, por una parte, y los arquitectos académicos, como Vicente Gascó y Antonio Gilabert, motivaron muy directa- 


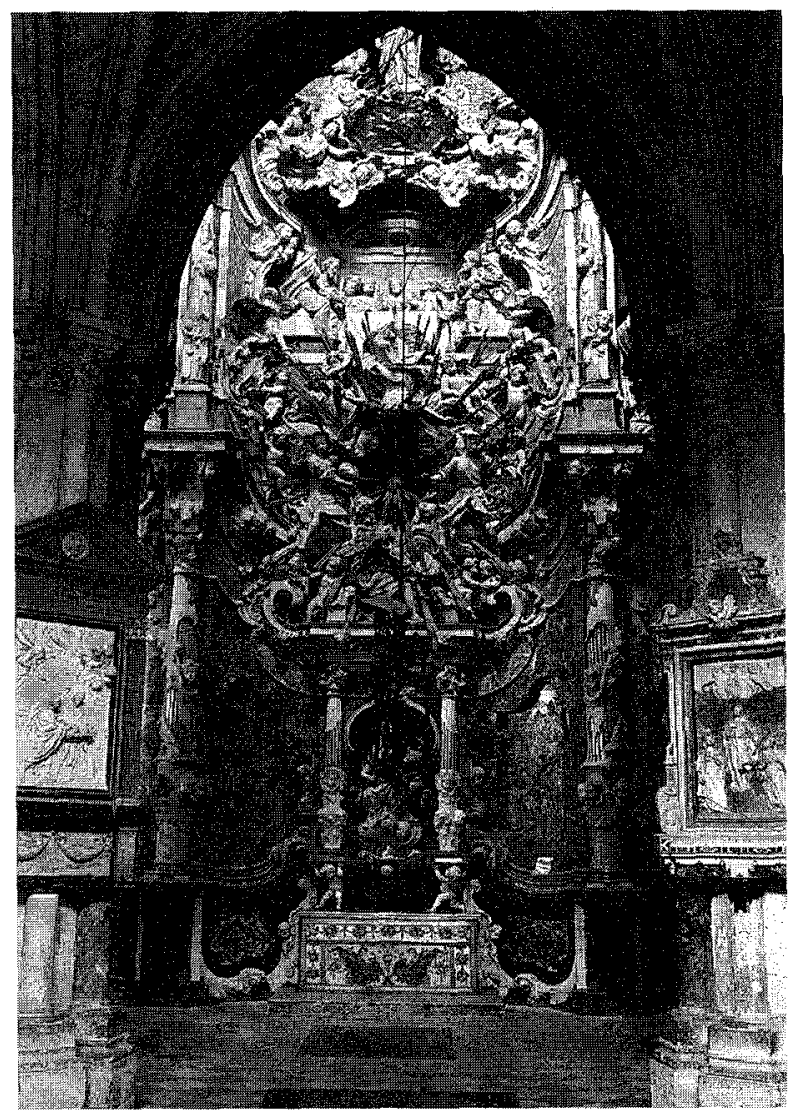

Fig. 1. Transparente de la Catedral de Toledo. Inaugurado el 9 de junio de 1732. Narciso Tomé.

mente las reivindicaciones de la Academia de San Fernando, aunque dándolas un novedoso matiz personal. Las relaciones existentes entre una y otra fueron transcendentales en estos años, pues el instituto madrileño asumió toda la problemática del valenciano, no sólo como portavoz de ella, sino como si fuera propia. Además, hay que destacar que, si aquél reflejaba la realidad artística en el medio cortesano, absolutista y centralista, este último transmitía, como ejemplo importante, todo lo que estaba acaeciendo en la periferia de la Corte, en las provincias. Eran las dos caras distintas, pero que constituían un todo indivisible, de una misma moneda.

En aquellos años de inicio, o de aspiración, de un nuevo renacimiento del clasicismo se identificaban los errores del lenguaje barroco con el 
abuso de una decoración excesiva. No había una oposición sistemática en España hacia las complejas estructuras arquitectónicas de los edificios, que parecían no ser cuestionadas. Es más, en un principio la mayoría de las veces los dialectos híbridos barrocos - clasicistas al modo francés e italiano fueron plenamente identificados con ese clasicismo, al cual se aspiraba. Se hacía coincidir, así, al barroco con la ornamentación exuberante, que tales artistas realizaban tanto en los retablos como en las fachadas y, en particular, en las portadas de las construcciones, pensadas, precisamente, como una variable de esos mismos retablos. No es, por lo tanto, extraño que la crítica se iniciara contra estas obras tan aparatosas y que explícita o implícitamente estuvieran comprometidas en ella de una forma conjunta los distintos profesionales de las Bellas Artes y en casi todas sus categorías.

También hay que destacar aquí cómo la polémica, que durante estos años la Academia entabló bajo el apoyo prestigioso de su vinculación directa con el Rey siempre a través de su protector, se centraría contra dos instituciones importantes, la una política y la otra facultativa: el Consejo de Castilla, en calidad de organismo político superior, que entonces perdería el poder sobre las Bellas Artes, y los gremios, como asociación profesional de vieja tradición, realmente perseguidos en este período, además de desplazados por los artistas formados en ese centro artístico. Uno y otro organismos estaban siendo marginados como núcleos de poder tradicional en el campo del arte desde la fundación de la Academia. La resistencia tenía, por lo tanto, una cierta lógica, basada en su pasado prestigio, en una historia de varios siglos de existencia.

Los objetivos perseguidos por la Academia también eran dobles: asegurarse el control pleno sobre la enseñanza, la teoría y la práctica del arte, e imponer el empleo del clasicismo como lenguaje artístico representativo de la Monarquía de los Borbones y de su Reino, que se incorporaba, así, al arte europeo. Es precisamente el uso de esta tendencia el elemento diferenciador con respecto a esos gremios y su principal aportación más novedosa al incorporarse España al estilo internacional entonces en uso en los países más cultos de Europa, como, sobre todo, Francia e Italia, los dos centros de referencia, y romper con su aislamiento ya casi secular. Pero no puede obviarse aquí toda la problemática económica, que se manifestaba de dos formas distintas: el clasicismo era un arte a la larga más barato por su desornamentación y su mayor persistencia en el tiempo debido al empleo de materiales nobles, $y$, asimismo, la lucha por hacerse con la totalidad de las obras de arte por parte de los artistas académicos contra los gremiales. 


\section{ETAPAS EN LOS ORIGGENES DE LA COMISIÓN DE ARQUITECTURA DE 1786}

Es posible señalar aquí dos fases distintas previas a la creación de la Junta de Comisión de arquitectura: el período $1768-1777$ bajo la secretaría de Ignacio de Hermosilla, y el comprendido entre los años 1777, fecha en la que el Conde de Floridablanca accedió al cargo de protector de la Academia, y 1786 con la actuación de Antonio Ponz como su secretario. En el segundo período este organismo ya ejercería ese control sobre los diseños de las obras de arte en sus juntas ordinarias, labor censoria que después asumiría plenamente tal Comisión al crearse en 1786.

La primera etapa estuvo marcada por la redacción en dos fases (17681770 , y 1777) por parte de los consiliarios y artistas de una serie de representaciones dirigidas al Rey Carlos III con la idea de controlar desde la Academia cuantas obras de arte se realizaban en España, que inspirarían las Reales Ordenes Circulares de 1777 con gran fidelidad. Es el momento de las reivindicaciones academicistas, de la lucha por alcanzar su plena autonomía política y de formación de un complejo proceso administrativo bajo la influencia y la intromisión continua del todopoderoso Consejo de Castilla, por el cual pasarían en el momento inicial los proyectos arquitectónicos para su censura en la Academia siempre en un primer y en un último lugar.

La década siguiente, 1777-1786, durante la cual tal centro de las Bellas Artes ejerció ya su tarea de inspección, se caracterizó por la lucha para acabar con esa injerencia continua del Consejo de Castilla en esta labor e imponer la práctica efectiva de esas Reales Ordenes de 1777. La Real Resolución del 17 de octubre de 1779 dispuso que los proyectos arquitectónicos no fueran enviados a este organismo político hasta que pasaran previamente la censura de la Academia ${ }^{2}$. Pero en 1783 el Consejo todavía seguía remitiendo a ese centro los diseños. Se complicaba, así, mucho el necesario proceso administrativo y se retardaban las resoluciones. Además, este sistema burocrático entrometía a tal órgano de gobierno en las labores propias de ese instituto de las Bellas Artes, vinculándolo con nexos de dependencia. Se quebraba de esta forma su autonomía en el campo artístico.

Esta resolución se basaba en el acuerdo de la junta particular del 8 de agosto de 1779. Hay en el A.A.S.F. una copia de la carta remitida por Antonio Ponz al protector sobre tal asunto, fechada el 12 de agosto de 1779, que se encuentra en el legajo 28-1/2. El texto de la real resolución del 17 de octubre de 1779 se recogió en las actas, firmadas por Isidro de Granja, de la junta particular del 6 de julio de 1783: A.A.S.F.: 3/123, fol. 260 rev. -262 anv. 
Antonio Ponz, nombrado secretario de la Academia el 1 de septiembre de 1776 por Resolución Real y sin consultar antes a la junta particular y en contra de la idea de los consiliarios, es, sin duda, el académico más destacado por su actividad en esta fase previa inmediata a la creación de la Comisión de arquitectura ${ }^{3}$. Buen conocedor de la Antigüedad clásica durante su viaje a Roma, de las ideas de Mengs y de la ideología de este centro, en donde se había formado como pintor desde la junta preparatoria, reflejó el espíritu académico tanto en su "Viaje de España", cuyos seis primeros tomos se publicaron antes de que ocupara este empleo, como en su actuación durante el tiempo que permaneció en el mismo, hasta 1790 . Se le puede considerar como uno de los principales inspiradores de las Reales Cédulas Circulares de 1777, que se basan en las representaciones de 1768 y en buena parte también en la carta redactada por el propio Ponz el 2 de julio de 1777 sobre el pensamiento de la Academia con relación al pleito del Gremio de Carpinteros de Valencia con la Real Academia de San Carlos de esta ciudad ${ }^{4}$. Trabajador incansable controló personalmente la gestión burocrática del proceso administrativo del proyecto arquitectónico entre 1777 y 1786. La creación de la Comisión de arquitectura se debió precisamente a su gestión al complicarse esa actividad por el gran número de proyectos, que llegaban a la Academia para su censura, y al sentirse incapaz de continuar y controlar perfectamente esta labor.

Con la creación de la Junta de la Comisión de arquitectura se dejó de supervisar estos dibujos en las juntas ordinarias de la Academia con la asistencia y opinión conjunta de los distintos académicos, tal y como se hizo durante el período 1777-1786. Desde este último año esa labor sería realizada por los profesionales especializados en la arquitectura, no interviniendo en la inspección, salvo en casos excepcionales, los demás profesores y

\footnotetext{
3 Antonio PONZ fue nombrado secretario de la Real Academia de Bellas Artes de San Fernando por la real orden del 1 de septiembre de 1776, leída en la junta particular de la Academia del 9 de septiembre. Actas de la junta particular del 9 de septiembre de 1776. A.A.S.F:: 3/123, fol. $21 \mathrm{rev}$. Tal nombramiento, que fue originado por la promoción de lgnacio de Hermosilla a la plaza de oficial de la Secretaría del Despacho de Indias, provocó la protesta de los consiliarios en dicha junta ante el protector por esta designación sin que antes se la hubiera consultado, tal y como los Estatutos señalaban. Dicho tema fue asunto monográfico en la junta del 22 de septiembre de 1776, ibídem, fol. 23 y ss. Véase también el artículo de Claude Bédat, "Antonio Ponz, secretario de la Real Academia de San Fernando. Polémica en torno a su nombramiento". "Academia", núm. 29, págs. 17-29. Madrid, Real Academia de Belias Artes de San Fernando, segundo semestre de 1969.

4 Esta carta de Ponz de un gran interés en este asunto de los orígenes de las cartas circulares de diciembre de 1777 se recoge en las actas de la junta particular de la Academia del 25 de junio de 1777. A.A.S.F.: 3/123, fol. 61 anv. -66 rev.
} 


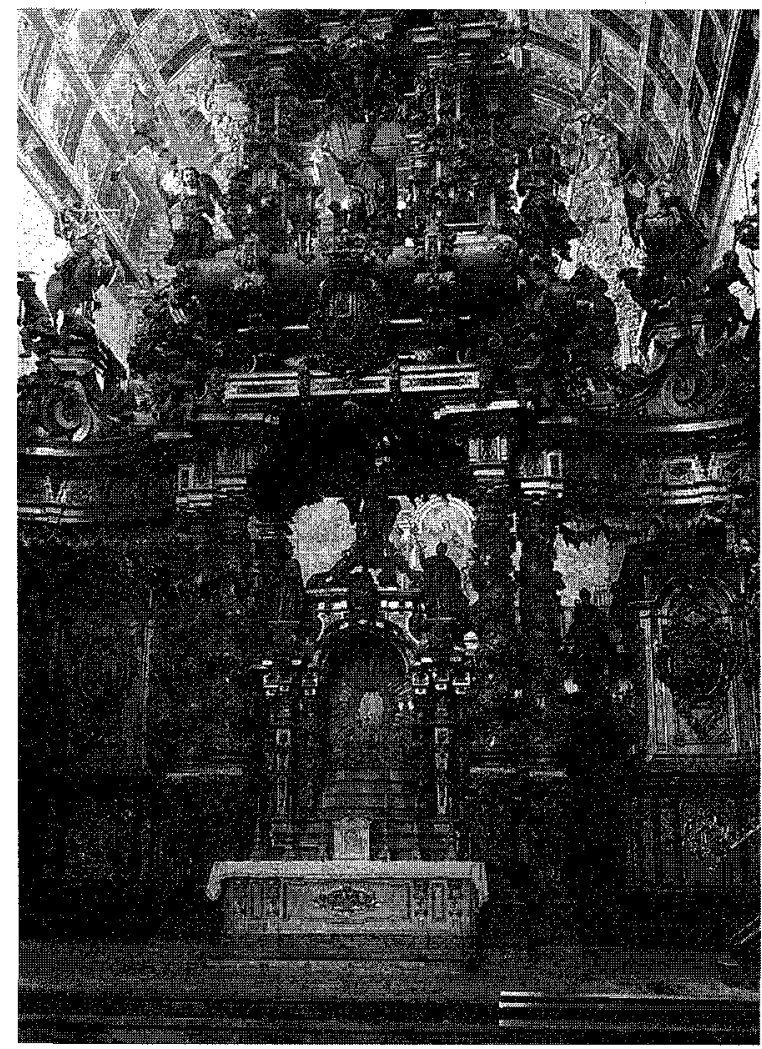

Fig. 2. Retablo mayor de San Martín Pinario. Santiago de Compostela. Trazas de Fernando de Casas y ejecución de Miguel de Romay 1730-1733.

consiliarios. No obstante, lo acordado en esas reuniones tenía que ser aprobado por las juntas ordinarias, lo cual se solía hacer prácticamente sin ningún problema, figurando también en las actas de las juntas particulares.

\section{LOS ORÍGENES REMOTOS DE LA COMISIÓN DE ARQUITECTURA: $1735-1768$}

Juan Pascual y Colomer escribió en 1818 un interesante informe titulado «Exposición de antecedentes sobre la presentación de los planos de obras públicas a censura de la Academia», en el que analizó desde una óptica legislativa la labor realizada por este centro de las Bellas Artes para lograr hacerse con el control y la censura de cuantos proyectos se diseñaban en 
España ${ }^{5}$. Lo redactó debido a la duda suscitada en la junta ordinaria del 8 de marzo de ese mismo año sobre si los académicos de mérito estaban sujetos a la presentación y examen de sus planos de obras públicas. Concluyó que debían hacerlo, porque no había habido ninguna disposición posterior ni acuerdo ni orden ni resolución alguna, que les eximiera de esta norma. Además, se hacía eco del sentir académico expuesto en las actas trienales impresas de 1796, que afirmaba que ninguna de las artes estaba tan expuesta, corría tanto riesgo, a viciarse y corromperse como la arquitectura.

Analizó brevemente, así, en su exposición las distintas disposiciones que desde el año 1730 se habían dictado para conseguir dicho control. Sin embargo, sus conclusiones no podían ser menos positivas, pues comenzó quejándose de que, aunque se había trabajado en este sentido para contener los desórdenes de la impericia y de la licenciosidad durante casi un siglo entero, no se habían alcanzado los objetivos deseados, tal y como lo demostraban las distintas noticias suministradas por los documentos del Archivo de la Academia.

Inició su informe documentando la queja que en 1735 Pedro de Ribera, maestro mayor de Madrid, presentó ante el Consejo debido a los perjuicios, que los profesores ignorantes de la teoría y de la práctica arquitectónica producian al público. Este órgano de gobierno, después de oír varios informes y los dictámenes fiscales, decidió que se formasen unas ordenanzas de policía. La Congregación de Arquitectos de Nuestra Señora de Belén de la parroquia de San Sebastián se encargó de redactarlas. Pero el borrador no pasó de orden del Consejo hasta el 3 de julio de 1750 a la junta preparatoria de la Academia, que se desentendió de ellas hasta que tuvo aprobados sus primeros Estatutos el 8 de abril de 1751 y hasta que fue elevada el 12 de abril de 1752 al grado de Academia real.

Las ordenanzas de policía de la Congregación fueron reconocidas en una junta ordinaria, en la cual se acordaron una serie de medidas encaminadas a su rectificación. Se propuso que el corregidor del ayuntamiento de Madrid nombrase dos diputados para arreglar dichas ordenanzas en base a la práctica de la arquitectura junto con otros tantos miembros de la Congregación y los directores de arquitectura de la Academia. Las personas designadas por el ayuntamiento redactaron junto con estos últimos una serie de puntos, que fueron aprobados en la junta ordinaria. Después, en la del 1 de agosto de 1754 se acordó enviar al Rey una consulta, firmada por todos los vocales el día 11 de ese mismo mes, que constaba de catorce artículos. Entre otros

5 PASCUAL y COLOMER, Juan: «Exposición de antecedentes sobre la presentación de los planos de obras públicas a censura de la Academia». Madrid, 4 de abril de 1818. 8 fols.. A.A.S.F.: leg.: 30-4/1. 
temas se pretendía en el artículo tercero, que los arquitectos reales y el mayor de Madrid tan solo pudieran ser elegidos entre los profesores directores o académicos de mérito. Además, en el cuarto se indicaba que ninguna persona pudiera idear ni dirigir ninguna fábrica, por pequeña que fuese, en la Corte, ni edificios públicos de consideración fuera de ella, sin que tuviera el requisito de ser académico de mérito por la arquitectura; de no ser así se le multaría con la pena de cien ducados aplicados al arbitrio real. Pero, además, se indicaba en el artículo quinto que las plantas y los diseños hechos por ellos no se podrían ejecutar sin que antes fueran vistos y aprobados en la Academia, imponiéndolos en el caso contrario la misma multa ${ }^{\circ}$,

\section{LA FASE INICIAL DE LAS REPRESENTACIONES AL REY: 1768-1776.}

Este período de 1768 a 1777 se inició con una fase muy problemática durante los años 1768 y 1769, tanto para la arquitectura como en la ideología de la Academia al romper Mengs con este organismo en 1770 por una serie de agravios comparativos. No obstante, a pesar de haber abandonado físicamente entonces este centro, sus ideas habían ya penetrado profundamente, confundiéndose con su mismo espíritu como institución de las Bellas Artes.

Asimismo, en 1768, año durante el cual Pedro de Silva y Jorge Juan fueron nombrados académicos de mérito de arquitectura con voz y voto en todos los ramos de esta facultad ${ }^{7}$, se solicitó a Ventura Rodríguez, como director general, la redacción de un informe sobre los abusos, que se estaban cometiendo en la práctica de la arquitectura. No cumplió este encargo, aunque la junta particular se lo solicitó repetidas veces, dándole como plazo final el último día de este año. Si no lo redactaba, debería devolver a la junta particular cuantos antecedentes y papeles se le habían entregado para este fin. El arquitecto se disculpó a finales de noviembre, alegando que no lo había hecho ya por sus muchas ocupaciones ${ }^{8}$.

\footnotetext{
6 Sobre la Cofradía de los arquitectos de Nuestra Señora de Belén y estos orígenes remotos de la creación de la Junta de Comisión de Arquitectura es preciso referirse al libro: BEDAT, Claude, «La Real Academia de Bellas Artes de San Fernando (1744-1808)". Madrid, Fundación Universitaria Española Real Academia. 1989. Véase el capítulo I, «La lucha contra las cofradías para la liberación del arte», págs. 333-369, de la tercera parte, «El papel de la Academia en el desarrollo del arte en España».

Borrador del oficio notificando a Pedro de Silva y a Jorge Juan sus nombramientos como académicos de mérito, fechado en Madrid el 9 de mayo de 1768. Tal designación tuvo lugar en la junta ordinaria del 8 de mayo. Jorge Juan dio las gracias al secretario de la Academia, Ignacio de Hermosilla, en carta datada en Madrid el 3 de junio de ese mismo año. AASF: leg.: 43-1/1.

${ }^{3}$ "Actas de la junta particular del 27 de noviembre de 1768. A.A.S.F.: 3/121, fol. 251 rev. En esta junta se previno a Ventura Rodríguez, para que despachara cuanto antes el informe que, para remediar los abusos que se cometían en la práctica de la arquitectura, se le había pedido. Se le
} 


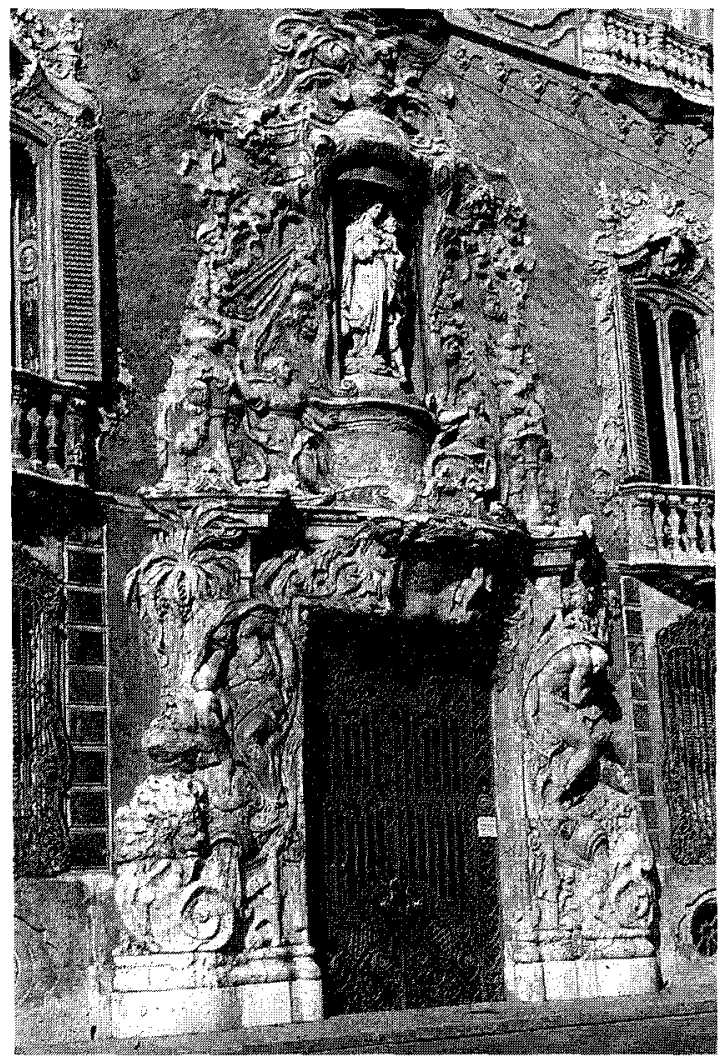

Fig. 3. Palacio del Marqués de Dos Aguas en Valencia. 1740-1744. Diseño del pintor Hipólito Rovira. Esculturas de Luis Domingo e Ignacio de Vergara.

\subsection{El plan de exámenes de Arquitectura de Diego de Villanueva}

Sin embargo, Diego de Villanueva, director de arquitectura, que en estos momentos, tal y como siempre había ocurrido, mantenía duras polémicas con Ventura Rodríguez, envió voluntariamente un interesante «Plan de exámenes de arquitectura», fechado el 15 de octubre de 1768, que fue presentado por el secretario Ignacio de Hermosilla a la junta particular del 27 de noviembre. Se acordó en esta reunión tenerlo presente

dio como plazo máximo el último día del año. En el caso de que no lo redactara, debería devolver a Ignacio de Hermosilla, secretario de la Academia, todos los antecedentes y papeles, que para este fin s€ le habían entregado. 
- parecía una ironía - para cuando el director general hiciera su informe, que le estaba ordenado sobre los abusos en la práctica de esta facultad. Se resolvería lo más conveniente a la vista de tales escritos ${ }^{9}$.

Diego de Villanueva incluía en este plan la ciencia del arte de la arquitectura en tres operaciones -medir, tasar y dirigir las obras artísticas-, que hacía corresponder con otras tantas partes vitruvianas de esta disciplina: firmeza, comodidad y hermosura ${ }^{10}$. Su programa se basaba en la enumeración de los diferentes conocimientos particulares necesarios para alcanzar el nivel preciso a fin de conseguir el título respectivo y poder ejercer las distintas profesiones. Cada uno de estos estudios debía ser explicado por un profesor especializado en una de estas clases específicas. Los discípulos no podrían pasar de un curso a otro sin tener previamente aprobado el anterior. Recibirían los títulos correspondientes de medidores, tasadores y directores en el caso de haber aprobado los exámenes según la parte cursada.

El programa aumentaba gradualmente en complejidad en función de cada tipo de estudios. En la primera clase, dedicada a la enseñanza de la medida, se exigirían estudios de geometría y aritmética para conocer las líneas, las superficies y los sólidos y sus medidas respectivas. Se plantearían en tal aula aquellos problemas que fueran considerados como más a propósito, eligiéndose siempre aquellos que necesitaran resolverse con el empleo de alguna operación aritmética. El segundo curso trataba sobre la tasación de las obras y el conocimiento de su solidez. Se enseñaban en él la Estática, la Imaginaria, montea, carpintería y albañilería, y se aprendían los distintos usos de la cal, la madera, el ladrillo, la piedra y los metales.

Tal y como parece obvio, era el tercer nivel según el programa de Diego de Villanueva, el dedicado a la dirección de las obras, el más complicado de todos ellos. Basado especialmente en el aprendizaje de las reglas de la proporción según la tratadística, se estudiarían en él las proporciones de los edificios en general en el todo y en cada una de sus partes tanto de sus exteriores como de sus interiores, su aspecto, y su situación. Punto primordial era el conocimiento de los ordenes arquitectónicos empleados en las construcciones y también en sí mismos considerados, analizándose, además, cuándo y en qué casos se debían usar. Pero también se estudiaría la arquitectura antigua, que Diego de Villanueva parece hacer coincidir

\footnotetext{
9 VILLANueVA, Diego de, «Plan de exámenes de Arquitectura». Madrid, 15 de octubre de 1768. 2 fols.. A.A.S.F.: leg.: 28-2/1. Fue presentado a la junta particular del 27 de noviembre de 1768, Actas (1757-1769), fol. 352 rev. y 353 anv.. A.A.S.F.: 3/121.

10 Vitruvio, "Los Diez Libro de Arquitectura". Madrid, Imprenta Real, 1787. Libro primero, capítulo III, De las partes en que se divide la Arquitectura.
} 
en este proyecto de exámenes exclusivamente con la griega, así como su aplicación a los edificios de la época según unas normas derivadas de los usos y de las costumbres.

Los diferentes estilos de la decoración empleados en las distintas naciones serían, asimismo, objeto de aprendizaje para los discípulos de la Academia aspirantes a la dirección de las obras arquitectónicas. En estas clases se analizaría el más adecuado para producir la hermosura positiva de los edificios y si tal condición se podría conseguir sin el uso de la ornamentación.

Diego de Villanueva propuso en su plan de exámenes de arquitectura que los aspirantes realizaran unos planos de repente y de pensado de una obra. Sobre estos proyectos indicarían qué proporciones habían seguido en cuanto el todo y sus partes, y lo perteneciente a su comodidad según la calidad del edificio diseñado. Por último, explicaría un tema sacado a suerte del tratado de Vitruvio o de algún otro autor, que se juzgara conveniente.

Hizo coincidir cada uno de estos tres títulos de profesionales de la arquitectura con el trabajo en un tipo diferente de obra. Los medidores se encargarían de realizar reparos menores, como eran los blanqueos, trastejos y otras maniobras de esta especie. Los tasadores, además de estar capacitados para tales menesteres, se ocuparían de las reedificaciones. Los directores proyectarían las obras nuevas y tan sólo se elegirían a los académicos de entre ellos.

Por último, Diego de Villanueva estableció la necesidad de promulgar dos providencias para poder cumplir tal proyecto. En primer lugar, se necesitaba traducir al castellano las distintas doctrinas, que sobre las partes expresadas en el plan, se hallaban escritos en lenguas extranjeras, así como reimprimir las ya existentes en español. Estos tratados servirían de libros de texto, estando la Academia obligada tan solo a enseñar aquellos aspectos o cosas, que necesitaran una explicación de viva voz. Pero también se deberían disponer estudios por diferentes profesores, que enseñasen cada una de las clases por las mañanas o por las tardes. Para ello puso como modelo el sistema establecido en París por Blondel, que este director de arquitectura se comprometía a explicar en el caso de que fuera necesario.

Terminaba su plan, al que Diego de Villanueva añadió una memoria, en la que se quejaba de las pocas horas empleadas cada año en los estudios nocturnos, diciendo escépticamente: «Es menester desengañarse que los estudios, como hoy están establecidos, jamás producirán un solo Arquitecto, pues solo con ellos se pueden sacar hombres de buena deli- 
Orígenes del control de los proyectos de obras públicas por la Academia...

neación, y nada más, como asimismo se probará siempre que sea conveniente». Esta idea coincidiría con la opinión que años después Antonio de Varas dio sobre el estudio de la arquitectura en la Academia ya en $1792{ }^{11 .}$

El proyecto de Diego de Villanueva guarda cierta relación con el dictamen del Conde de Aranda sobre los estudios de la arquitectura de hacia el año $1757^{12}$. Basándose en los tres principios clásicos de que consta esta disciplina de firmeza, hermosura y comodidad estableció otras tantas partes en su curso. Se corresponden respectivamente con los tres grados de medidores, directores y tasadores de Villanueva. Coinciden en algunas de las distintas disciplinas, las principales, que debían aprender en cada clase. Así, el Conde de Aranda, como este arquitecto, indicaba que para la firmeza de la fábrica debía conocer la aritmética y la geometría; pero también se estudiarían los materiales y sus usos, las calidades de los terrenos, el modo de fabricar en todas sus especies, la carpintería, blanqueos y construcción de maquinarias pertenecientes a la arquitectura. En la hermosura era imprescindible para el consiliario, como para Villanueva, el estudio de los cinco géneros de edificios antiguos y los ordenes, así como la perspectiva y la óptica. Para la comodidad se debían tener conocimientos de la situación y disposición de las fábricas, de la fortificación, de los templos, de las plazas y demás edificios públicos y de las casas particulares. La política de traducciones y reediciones propuesta por Diego de Villanueva se halla también en la misma línea docente de la del Conde de Aranda, en gran parte cumplida por la Academia durante las dos décadas finales del siglo. Así, el consiliario quería traducir el Vitruvio de Perrault, a Serlio, Scamozzi, Alberti y Palladio.

Diego de Villanueva estaba familiarizado con este dictamen sobre los estudios de arquitectura del Conde de Aranda. Se recordará aquí que en la junta ordinaria del 27 de enero de 1760 presentó, siguiendo los deseos del viceprotector Tiburcio de Aguirre, modelos de dos arcos con sus cimbras hechos de madera, y de las columnas toscana y dórica con sus respectivos basamentos y cornisas. El Conde de Aranda había propuesto en su plan de estudios que se formaran modelos como de los despieces de los arcos y bóvedas, que debían tenerse presentes en las explicaciones de las lecciones para facilitar su mayor comprensión.

También el día 4 de ese mismo mes el director de arquitectura había remitido un método para distribuir las ayudas de costa mensuales entre los discípulos de arquitectura. Además, daba razón del sistema que estaba

1 Varas y PORTILlo, A., "Discurso". Madrid, 9 de octubre de 1792. A.A.S.F.: leg.: 18-20/1.

12 ARANDA, Conde de, “Dictamen». A.A.S.F.: leg.: 1-18/9. 
establecido para ello en París desde el 6 de marzo de 1743 en la Escuela de Arquitectura. En esta ocasión se acordó en esa misma junta particular considerarlo a la hora de arreglar el estudio de esta facultad ${ }^{13}$.

No obstante, Diego de Villanueva, quien, quizás, estuviera desarrollando entonces toda esta actividad febril con una finalidad política, para ganarse la voluntad de la junta rectora de la Academia, sufrió un duro contratiempo en esa misma reunión. Había presentado a la junta ordinaria su libro «Tratado de delineación de los ordenes" para su examen, encargándose a Pedro Martín Cermeño de su lectura. El consiliario no halló estos tratados dignos de imprimirse figurando su autor con el título de director de la Academia. Aunque la junta no quiso admitir pruebas de la justicia de este dictamen, el académico leyó para mayor abundancia varios pasajes, que, en opinión de lgnacio de Hermosilla, calificaban «la prudencia y acierto de su opinión». Todo ello hizo que se acordase prevenir a Diego de Villanueva, que por causas justificadas no se le concedía la licencia para usar el título de director de la Academia en la impresión de dichos tratados ${ }^{14}$.

\subsection{La consulta de los escultores del 4 de diciembre de 1768}

Entre los meses de diciembre de 1768 y marzo de 1769, con secuelas en 1770 , se redactaron una serie de representaciones de la Academia dirigidas al Rey a través del protector, que tuvieron su réplica en los informes correspondientes de Pedro Rodríguez de Campomanes, por su calidad de fiscal del Consejo, cuyo pensamiento tanto político-administrativo como estético incidió decisivamente en el proceso crucial de 1777. Muchas de las ideas expuestas en esta documentación se reiterarían entonces casi literalmente. De ellas interesa destacar aquí una serie de aspectos importantes. Así, se manifiesta el interés común de consiliarios, artistas, protector, Rey, fiscal y miembros integrantes del Consejo por depurar las formas, alejar el barroco excesivo e implantar un nuevo clasicismo. Hay, además, un debate transcendental entre ambos organismos, entre la Academia y el Consejo, por tener más poder sobre las Bellas Artes. Se puede comprobar, asimismo, un hecho de interés social: el instituto académico estaba entonces totalmente

\footnotetext{
13 Actas de junta particular del 27 de noviembre de 1768. A.A.S.F.: $3 / 121$, fols. 352 rev. y 353 anv..

Ibidem, fol. 353 rev. de las actas de la junta particular del 27 de noviembre de 1768. Este asunto lo trató Alicia QuintanA MARTínez en "La Arquitectura y los arquitectos en la Real Academia" de Bellas Artes de San Fernando (1744-1774)", Madrid, Xarait Ediciones, 1983. Véase págs. 56 .
} 


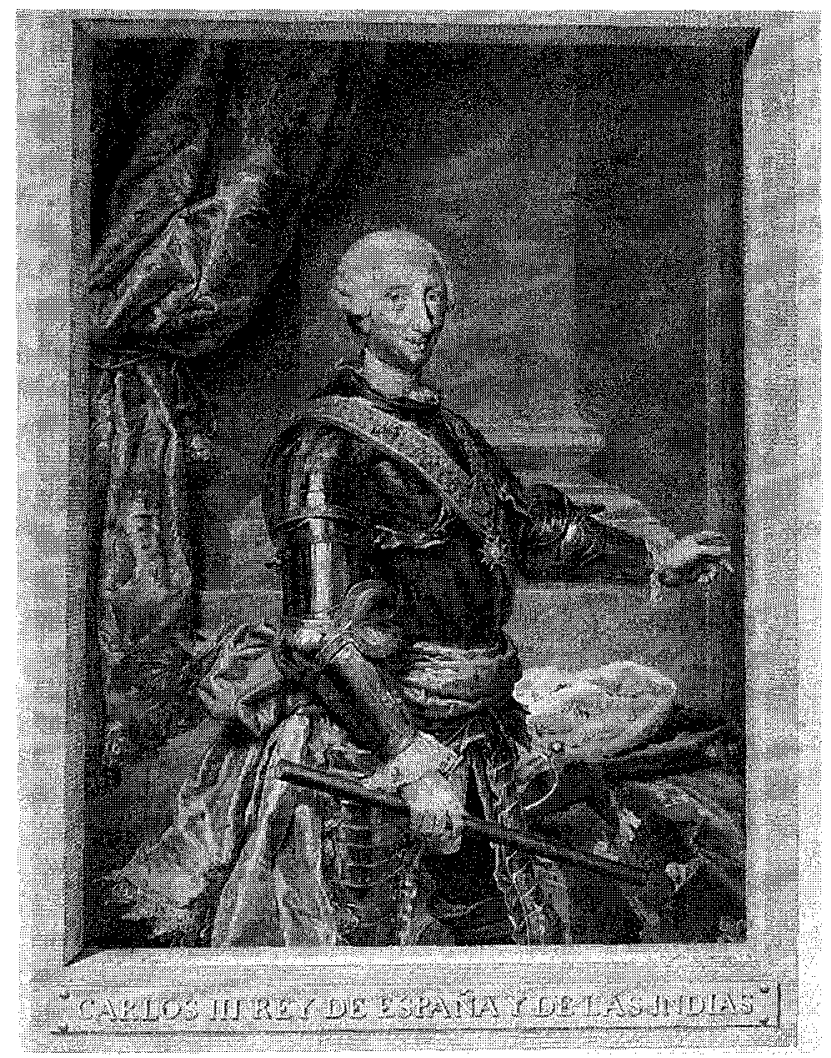

Fig. 4. Carlos III. Grabado de Manuel Salvador Carmona que se inspira en Mengs.

dividido entre un estamento nobiliario directivo, los consiliarios, y otro profesional subordinado. Los artistas se apoyarán en el fiscal y el Consejo para conseguir sus reivindicaciones, mientras que los consiliarios lo harán en el Rey transcendiendo así las guerras intestinas en el exterior. Las tertulias celebradas en casa del Conde de Campomanes debieron influir directamente en esta situación y en sus informes, pues Ventura Rodríguez, Mengs y Castro acudían a ellas. Por lo tanto, el Fiscal se hallaba al corriente de todo lo que ocurría en la Academia. Estos dos últimos pensaban que el instituto debía ser un organismo para los artistas y dirigida por ellos.

El proceso ideológico de los años 1768-1770 se inició con la consulta de los escultores del 4 de diciembre de 1768. Los profesores directores y tenientes directores de escultura Juan Pascual de Mena, Felipe de Castro, Francisco Gutiérrez y Manuel Álvarez, encabezados como era preceptivo 
por Ventura Rodríguez, un arquitecto, por su calidad de director general, enviaron esta consulta al viceprotector, en la cual se solicitaba que fuera obligatorio estar aprobado por la Academia para poder ejercer la escultura en España. Además, se quejaban en ella de los perjuicios sufridos por este género artístico debido al gran número de sujetos inhábiles y sin ningún estudio, que lo cultivaban. La impericia se acompañaba, así, con el bajo precio pedido por las realizaciones de tales obras, lo cual hacía que se llenase tanto la Corte como la Nación de estatuas e imágenes indignas de colocarse, y que los buenos artistas se quedasen sin trabajo. De esta forma se defraudaba el mérito de los profesores y se impedían los progresos, que la Academia procuraba lograr ${ }^{15}$. Hay, así pues, una reivindicación profesional y económica de gran interés.

En la representación se pedía al protector, que comunicara todos estos inconvenientes al Rey. Deseaban que Carlos III expidiera una Real Orden, prohibiendo a quienes no estuviesen aprobados antes por la Academia, esculpir ni hacer escultura alguna. También solicitaban que se vetara con grandes penas a los retablistas, que ajustaran esculturas para retablos, pues tal labor tan sólo la deberían realizar los escultores. De esta forma los mejores artífices tendrían qué hacer, formarían buenos discípulos, brillaría el arte y el Rey dispondría de excelentes artistas. Hay, por consiguiente, un claro afán reivindicativo de los escultores de la Academia de carácter social y hasta económico frente a los gremios, sentido que en gran medida aquí se superpone al deseo de imposición del clasicismo, quizá un motivo más aparente $o$ un pilar conceptual en donde sustentarse. Pero también hay que destacar aquí que los escultores académicos madrileños se atribuían la realización del retablo, sin mencionar a los arquitectos para nada.

\subsubsection{Precedentes valencianos de la consulta}

Como precedente de esta representación hay que referirse aquí necesariamente a los problemas habidos en la Real Academia de San Carlos de Valencia -estudiados en profundidad por Bérchez-, cuyos Estatutos se publicaron el 14 de febrero de 1768, en el mes de julio de este mismo

\footnotetext{
15 Esta representación de los escultores, fechada el 4 de diciembre de 1768 , se halla en A.A.S.F.: leg.: 1-3/28. Bédat se refiere a ella en las págs. 349-351 de su libro " $L a R e a l$ Academia de Bellas Artes de San Fernando (1744-1808)". Madrid, Fundación Universitaria Española - Real Academia de Bellas Artes de San Fernando, 1989. La publicó Andrés Úbeda de los Cobos en el vol. Il dedicado a documentación, págs. 317-319, de su libro titulado "Pintura, mentalidad e ideología en la Real Academia de Bellas Artes de San Fernando. 1741-1800". Madrid, Editorial de la Universidad Complutense, 1988. También: AASF : 28-1/2.
} 
año al pretender el maestro carpintero Vicente Esteve ser examinado de arquitecto por el instituto. La falta de respuesta de la junta ordinaria del 24 de julio de 1768 de la Academia valenciana -en contra de los deseos de Ignacio Vergara y Jaime Molíns, sus directores de escultura- motivó que aquél junto con otros artistas del gremio de carpinteros, titulándose escultores y arquitectos adornistas o retablistas, dirigieran un memorial, fechado el 30 de julio, a la Academia de San Fernando haciendo colectivo el deseo de Esteve ${ }^{16}$. Pretendían realizar, al examinarse, su práctica según los Estatutos de ese centro, así como gozar de los beneficios, privilegios, exenciones y prerrogativas, que la aprobación del título proporcionaba. Además, sólo aspiraban a ejercer de la arquitectura la especialización propia de escultura y arquitectura adornista, aunque esta disciplina fuera indivisible según los Estatutos. También denunciaban ante la Academia de Madrid al arquitecto académico Vicente Gascó por oponerse a sus deseos porque no conocían las ciencias matemáticas y tan sólo practicaban el estudio de los cinco órdenes. Le acusaban de que quería inmiscuirse lucrativamente en su profesión, pues aspiraba a ser quien proyectase los diseños de los retablos, relegándolos a la simple ejecución de su idea. Asimismo, hay que destacar la problemática que encierra el retablo, que los arquitectos se atribuían en contra de los deseos de los escultores.

Ignacio de Hermosilla, secretario del instituto madrileño, envió el 12 de agosto de 1768 al valenciano una copia de tal memorial de los escultores y retablistas de esa ciudad para su informe, que fue encargado a Francisco Navarro en la junta particular del 2 de octubre ${ }^{17}$. Se trataba de asegurar el decoro de la Real Academia valenciana. Este consiliario se asesoró de los dos directores de arquitectura a la hora de redactarlo definitivamente, tras de realizar varios borradores. La respuesta se basaba en la idea de la indivisión de la arquitectura en partes distintas y en la complejidad de los estudios de esta disciplina, que requería el conocimiento de otras ciencias complementarias ${ }^{18}$. Además, tal y como Bérchez señala acertadamente, se aspiraba a "dotar a la arquitectura y a su ejercicio de una autonomía respecto a las demás artes y oficios que tanto una concepción barroca como gremial impedía» ${ }^{19}$. Se trataba también de se-

\footnotetext{
16 Joaquín BÉRCHEZ trata este asunto en su libro «Arquitectura y academicismo en el siglo XVIII valenciano", en el capítulo 9, págs. 183-203. Localiza los manuscritos en A.A.S.C.: leg. 67, núms. 56 y 105.

17 Ignacio de Hermositla: Sobre la denuncia de los retablistas. Madrid, 12 de agosto de 1768. A.A.S.C.: leg. 67 , núm. 56.

18 Se basaba en el artículo 31, número 7, de los Estatutos de la Real Academia de San Carlos.

19 BÉRCHEZ, ibidem, pág. 191.
} 
ñalar los límites entre las competencias de las tres Bellas Artes para que no entrasen en litigio. Francisco Navarro basó su respuesta en los Estatutos, pero también en Vitruvio, que promovían la indivisión de la arquitectura, como ciencia compuesta de muchos y variados estudios, y entre ellos de la aritmética y la geometría.

Hay que destacar aquí como la Academia valenciana se adelantaba en más de veinte años al debate entablado en 1793 entre el matemático Varas y los arquitectos de la Academia madrileña sobre la necesidad del estudio de esas disciplinas y el carácter científico de la arquitectura. Asimismo, es preciso referirse a que determinados aspectos indicados por Navarro - en realidad, Gascó - en su pugna contra el barroco a través del retablo fueron después empleados más o menos modificados por los académicos madrileños en sus representaciones de finales de 1768 y aún en

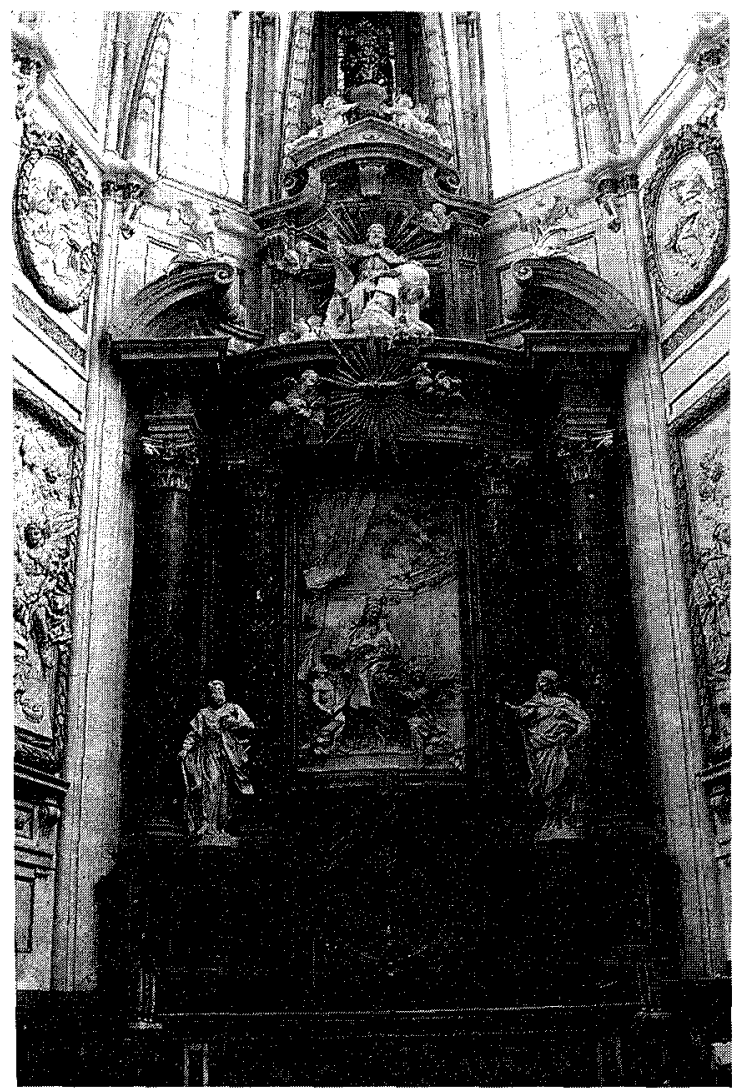

Fig. 5. Retablo Mayor de la Catedral de Cuenca por Ventura Rodríguez. 1752. 
1777. Pero resulta muy significativo que en los inicios fueran los escultores académicos madrileños quienes hicieran suyo el problema del retablo, que en Valencia los arquitectos consideraban como un elemento arquitectónico propio de su profesión, al menos en su proyecto y dirección de obras. Los arquitectos de la Academia de San Fernando no reivindicaron a los escultores su competencia sobre el diseño del retablo.

Hay otros muchos aspectos de gran interés en el debate valenciano, que repercutieron en el general promovido desde la Corte. En primer lugar, la idea de que la escultura estaba corrompiendo a la buena arquitectura. Ello se demostraba a través del retablo, donde era manifiesto el desorden como consecuencia de la superposición de distintos órdenes de arquitectura, el abuso en el empleo de la hojarasca, los excesos de formas curvas y retorcidas... Todo ello era la consecuencia de una demasiada libertad y de la ignorancia de las normas del buen gusto, que se hallaban en la tratadística de Vitruvio y de los teóricos del Renacimiento. Pero, además, detrás del debate había un doble problema económico: el del gasto excesivo producido por el empleo de la madera y los dorados, y la necesidad de que los artistas académicos desarrollasen su profesión al recibir encargos de obras.

\subsection{La representación de los consiliarios del 4 de diciembre de 1768 sobre los abusos cometidos por los tallistas, canteros, retablistas y otros artistas}

La anterior consulta debió ser analizada en la junta ordinaria del mismo 4 de diciembre e incidió en la redacción de la representación firmada por una serie de académicos consiliarios - los Marqueses de Sarriá, de Villafranca y de Tavara, el Conde de Baños, Pedro de Silva, Pedro Martín Cermeño y los hermanos José e Ignacio de Hermosilla- por determinación acordada en la junta ordinaria del 27 de noviembre. El escrito enviado al protector se ocupaba de los abusos cometidos por los tallistas, canteros, retablistas, albañiles y otros artistas subalternos, que podían idear y construir por sí mismos con absoluta independencia de la Academia retablos o altares de madera u otra materia, fuentes y portadas de edificios ${ }^{20}$. Todo

20 Representación de la Real Academia de San Fernando. Madrid, 4 de diciembre de 1768. Este documento se halla en el A.H.N., Consejos, leg. 2076, núm. 5. El texto fue publicado por Juan Carrete Parrondo en "Pedro Rodríguez de Campomanes. Informes sobre la Real Academia de Bellas Artes de San Fernando", en la «Revista de Ideas Estéticas", núm. 137, 1977, págs. 75-90. Una copia se conserva en el Archivo de la Real Academia de San Fernando en el legajo 28-1/2, que cité y estudié en: GARCIA MELERO, J.E., «Arquitectura y burocracia: el proceso del proyecto en 
ello había producido enormes imperfecciones, visibles frecuentemente tanto en los templos como en las calles de las ciudades, lo cual era considerado, además, como un auténtico estorbo para la instrucción de los jóvenes, que se acostumbraban a contemplar tales barbaries y mal gusto, asentándose tenazmente en su imaginación. De nada valían los estudios académicos, pues actuaban al margen de los Estatutos de la Academia y sin que este organismo estuviera autorizado a terminar con esos desmanes con penas proporcionadas. De aquí que se partiera de un motivo educativo, que tanto obsesionaba al Rey desde 1766, para pedir una reivindicación.

La Academia por todas estas razones había considerado necesario, que sus facultades se extendiesen para remediar tales daños. No obstante, se había abstenido hasta entonces de manifestarlo, para que no se confundiera su celo con la ambición. Se pensaba, además, que por medio de los estudios, la instrucción y la cultura se desterrarían del país estos abusos. Pero el instituto se había desengañado y perdido la esperanza, de que se consiguiera remediar todo ello por tales medios. "A pesar de los estudios en que tanto se trabaja", - se indicaba en esta representación«a pesar de los buenos ejemplos, que en templos y obras públicas se han dado, continúan los perversos retablos, las horribles portadas, los bárbaros adornos, y otros monumentos de la ignorancia» ${ }^{21 .}$

Se indicaba que una representación hecha en este mismo sentido por la Academia de San Carlos de Valencia -que tanto influencia tendría también en las disposiciones posteriores de 1777-, así como las experiencia propias y las maduras reflexiones, les había motivado finalmente a enviar este escrito al Rey. Se necesitaba terminar con esos abusos, porque convenía a su servicio, al bien público y al progreso de las artes.

Los consiliarios concluyeron su expresivo escrito pidiendo, y esto es lo más interesante, que en Madrid, Valencia y cualquiera otra capital, donde se estableciese una Academia, no se pudieran construir retablos o altares de madera, ni otra materia, fuentes, portadas de edificios públicos o casas particulares de consideración, sin que primero fueran presentados los diseños a este organismo, en el cual se reconocerían, corregirían y aprobarían sin ningún tipo de costos. Se debía también obligar a los artistas a ejecutar lo que se hubiera aprobado, sin libertad para variarlo. El examen, arreglo y corrección de los proyectos se haría por las Academias sin ningún tipo de costes, es decir, sin pedir derechos algunos ni a los dueños ni

la Comisión de Arquitectura de la Academia (1786-1808)", en "Espacio, tiempo y forma", serie VII, Historia del Arte, t. 4, 1991, págs. 283-348.

${ }^{21}$ Ibídem, fol. 1 rev.-2 anv.. 
Origenes del control de los proyectos de obras públicas por la Academia...

a los artistas. Se tomaba esta decisión tanto por la idea de facilitar más esta ventaja, como para que se viera que no había pretensión de lucro en la persecución de tales barbaries por parte de los artífices académicos. Por último, recomendaron que, con el fin de que la providencia tuviera efectos prácticos, se impusieran a los infractores las mismas penas, que en el artículo 33 de los Estatutos se establecían, a quienes ejercían la arquitectura sin título ni aprobación legítima.

Así, la Academia estaba preocupada desde hacía ya tiempo en tomar medidas correctivas contra los practicantes gremiales, que abusaban del barroco. El plan de exámenes de arquitectura escrito por Diego de Villanueva el 15 de octubre de 1768 confirma esta preocupación ${ }^{22}$. En la misma tapa de este documento se puede leer que la junta particular del 27 de noviembre de ese mismo año lo recomendaba para que el director general lo tuviera presente a la hora de redactar el informe, que se le había solicitado sobre los abusos en la práctica de la arquitectura. Las medidas correctivas de las obras entonces realizadas estaban en estrecha correlación con la enseñanza misma de tal disciplina. Unas y otras eran necesariamente interdependientes. Pero, además, se había razonado tal disposición por medio de motivos estéticos, didácticos, profesionales y hasta económicos.

\subsection{La representación de la Academia del 20 de diciembre de 1768}

Esta representación se relaciona estrechamente con la del 4 de diciembre de los consiliarios, ampliando sus peticiones, y, también y sobre todo, con la consulta de los escultores académicos de ese mismo día. Se quería extender el contenido del artículo 31 en su 4º punto de los Estatutos de la Real Academia de San Carlos de Valencia en la madrileña y en cuantas otras Academias se fundaran en las demás capitales en el futuro. Ahora este nuevo instituto levantino de las Bellas Artes incide en el organismo matriz a través de su sistema estatutario, aunque previamente se inspirase en sus Estatutos, pero depurándolos, actualizándolos y perfeccionándolos ${ }^{23}$.

El punto 4 ำ prohibía bajo multa de cincuenta ducados a todo pintor, escultor y grabador sin licencia de la Academia pintar, esculpir y grabar

\footnotetext{
22 VIllanueVa, Diego de, Plan de exámenes de arquitectura. Madrid, 15 de octubre de 1768.2 fols.. A.A.S.F.: Leg.: 28-2/1.

23 La representación de la Real Academia de Bellas Artes de San Fernando, fechada en Madrid el 20 de diciembre de 1768, se halla en A.H.N.: Consejos, leg.: 2086, núm. 7. Juan Carrete la publicó en «Pedro Rodríguez de Campomanes...», op. cit., pp. 84-86. La firmaron los Marqueses de Sarriá, de Villafranca y de Santa Cruz. el Conde de Baños, José e Ignacio de Hermosilla, Vicente Pignatelli, Pedro de Silva y Pedro Martín Cermeño.
} 
para el público imágenes sagradas. El Rey deseaba que se realizaran con la mayor perfección posible para que la impericia de los artesanos no prosiguiese «haciendo irrisibles los objetos de nuestra veneración". Para ello se mandaba a los individuos de la Academia valenciana que actuaran con toda justicia al no dar licencia a quienes no lo merecieran y concediéndola a los hábiles y beneméritos. Pero, además, no deberían exigir directa o indirectamente derechos ni dineros algunos.

La petición se basaba de nuevo tanto en aspectos estéticos como sociales y hasta económicos. Se indicaba previamente que se había reflexionado más en lo solicitado en la representación del 4 de diciembre, extendiéndose las consideraciones a la práctica de la escultura. La Academia advertía la desocupación de los escultores académicos, que se dedicaban a la enseñanza, y la de sus discípulos: «perecen miserablemente, si V.M. no los emplea en sus obras". Apenas había comunidad o particular que los contratase en la realización de las numerosas estatuas, sobre todo religiosas, que se esculpían cotidianamente para la Corte y fuera de ella. Lo cual se debía al poco tiempo que los retablistas y tallistas invertían en hacerlas especialmente en madera, debido a su desconocimiento del verdadero arte, al no estudiar ni reflexionar sobre ellas. "Ellos, u otros más rudos» -indican en la representación- «las hacen en pocos dias; pero tan deformes, que en lugar de excitar nuestra devoción, sólo sirven de mover la indignación de las personas cuerdas, y de multiplicar los monumentos de la ignorancia». La rapidez en la realización y la rudeza de la obra hecha permitía venderla a precios muy bajos, no pudiendo competir con quienes, poseedores del auténtico arte, invertían mucho tiempo en estudiar la figura, en hacer modelos y en perfeccionar las esculturas. De ahí sus costes más altos.

Las cuestiones estéticas, el nuevo clasicismo, se relacionan estrechamente con los motivos económicos en este documento tan expresivamente reivindicativo. El binomio calidad-precio parece confirmarse aquí. Había un claro problema de competencias profesionales en función de la ley del mercado, de la oferta y de la demanda relacionados con los precios. La Academia buscaba la calidad de la obra de arte en los dictados poéticos del clasicismo, que eran su sistema propio, y desacreditaba las pervivencias barrocas identificadas con los gremios; pero también trataba de conseguir el sistema perfecto para ocupar a los escultores salidos de su estructura docente. Para ello acudió al honor de la nación, a cortar los abusos que la desacreditaban, predisponiendo el ánimo religioso del Rey al incidir en su conciencia por medio de las imágenes sagradas. «Sólo los hábiles y beneméritos artífices tienen derecho a trabajar para el público y 


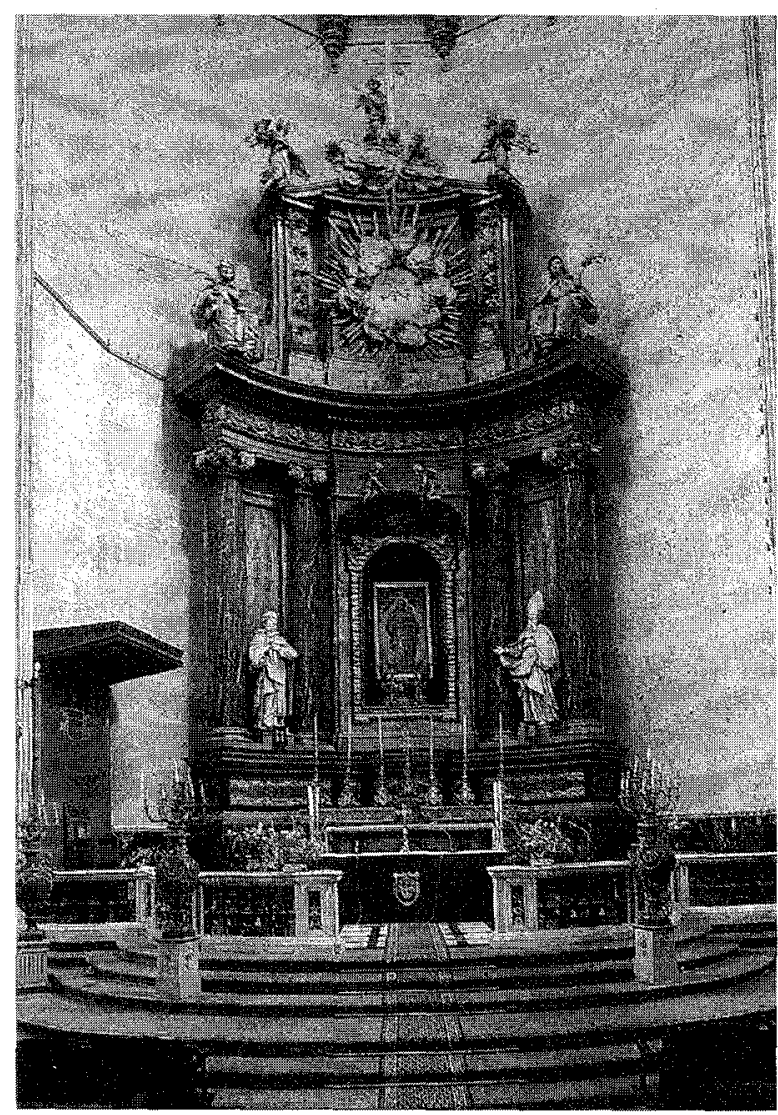

Fig. 6. Retablo Mayor de la Catedral de Segovia. 1768. Francisco Sabatini. Fue un modelo de nuevo clasicismo y se realizó en la época de las representaciones al Rey por parte de la Academia madrileña.

a ser recompensados honestamente por él; y entonces los mismos que en el día son meros y materiales tallistas, se verán obligados a estudiar, a deponer su barbarie, y a merecer los estipendios y honores de verdaderos artífices».

\subsection{La representación de los facultativos del arte de la escultura}

Los facultativos del arte de la escultura de la Corte enviaron una representación, fechada en Madrid el 30 de diciembre de 1768, al enterarse de la remitida por los directores de escultura de la Academia y como ré- 
plica a las razones contenidas en ella ${ }^{24}$. Se indicaba que tenían noticia de que éstos habían firmado una el 23 de ese mismo mes en la junta ordinaria de la Academia, que se celebró el mencionado día. Se quería contestar a la reivindicación académica, por la cual se deseaba hacer extensible a este organismo madrileño la gracia alcanzada por la Academia de Valencia: que ningún profesor de este arte pudiera ejercer, sin que primero pasase por la aprobación de dichos directores, debido a que en su opinión las obras realizadas por ellos eran irrisibles, porque trabajaban sin modelo, ni estudio alguno.

La réplica de los escultores gremiales se basaba sobre todo en una razón económica: los directores de escultura de la Academia, que abusaban de los precios de sus obras, querían hacerse con ellas a toda costa, eliminando la competencia. Alegaron, así, que, mientras aquellos «espantaban» por lo que pedían, ellos se contentaban con un moderado jornal para poder vivir, realizando el sobrante de las obras escultóricas, o las que no querían hacer dichos directores. Además, indicaron que todas, o la mayor parte, habían sido aprobados por ellos, siendo también del gusto de los mecenas. En su opinión éste -acaparar y cobrar lo que quisieranera el auténtico motivo de sus pretensiones y no «el aumento y perfección del arte». De aquí que intentasen inventar distintos modos de estorbarles.

Pero, asimismo, replicaron a los motivos educativos, con los que los escultores directores académicos habían razonado su representación del 4 de diciembre, demostrando conocerla perfectamente. Alegaban haber aprendido su arte desde la infancia y estar ocupados en esta actividad el que menos durante diez años. Pedían justicia al manifestar que se hallaban cargados de familia, que algunos eran ya ancianos, y que no tenían otro modo de vivir que el de ejercer la facultad aprendida. Por si tal súplica no bastara, aducían que varios de ellos habían estado matriculados en la Academia, realizado oposiciones y acudido a sus premios. Temían que, al deber ser aprobados por los directores de escultura de la Academia, y conociendo su intención, acaso ninguno lo fuera en tal prueba. Les parecía irregular que, quienes profesaban ya tan noble arte desde hacía tanto tiempo, debieran ser examinados. Por todas estas razones suplicaban, que la providencia solicitada por los profesores académicos, no tuviera efecto, y que las innovaciones tan sólo comenzaran por quienes enton-

24 La «Representación de los facultativos del arte de la escultura», fechada en Madrid el 30 de diciembre de 1768, se halla en el A.H.N., Consejos, leg.: 2076, núm. 7, y también fue publicada por Juan Carrete en op. cit., 86-88, "Pedro Rodríguez de Campomanes...". La firmaron en nombre de todos: José de Oñatte, Pablo Martínez, José Zazo, Tomás Calderón de la Barca, Fernando Gil y José Salvador Carmona. 
ces empezaban a aprender la facultad, eximiendo de ellas a los que ya estaban establecidos en la Corte.

\subsection{La respuesta fiscal del 10 de enero de 1770}

El Marqués de Grimaldi, secretario de Estado y, como tal, protector de la Academia, remitió el 7 de diciembre de 1768 al Consejo de Castilla de orden del Rey la representación de los consiliarios de este centro de las Bellas Artes del día 4 de dicho mes, para que a su vista diera su parecer. El fiscal de lo civil, Pedro Rodríguez de Campomanes, que lo era desde 1762 y lo fue hasta 1783, contestó a ese organismo político con bastante prontitud, el 10 de enero de 1769; pero no fue comunicada su respuesta a la Academia hasta un año después. El manuscrito original de este interesante texto se conserva en el Archivo Histórico Nacional y fue publicado por Juan Carrete Parrondo en $1977^{25}$.

No obstante, en el Archivo de la Real Academia de Bellas Artes de San Fernando hay un documento fechado el 23 de febrero de 1770 y sin firma, en cuyo margen izquierdo del encabezamiento figuran los nombres de una comisión presidida precisamente por el Conde de Aranda, como presidente del Consejo de Castilla desde 1766, y compuesta por Miguel $\mathrm{M}^{\mathrm{a}}$ de Nava, Andrés Maraver, Pedro León, el Marqués de San Juan, Francisco Losella y Pedro de Ávila. Podría tratarse, tal vez, de una copia en borrador del dictamen fiscal, remitido por el Consejo al viceprotector de la Academia para su entendimiento, ya que reproduce con exactitud el documento original, con la única diferencia de introducirse cada párrafo con la fórmula indirecta «que» en referencia a lo indicado por el Conde de Campomanes ${ }^{26}$. Quizá este borrador sea la aceptación oficial por el Consejo del dictamen fiscal, que asume como propio.

En la documentación del Archivo de esta Academia no se perciben las causas del retraso habido desde la redacción diligente del informe por el fiscal al Consejo, su envío al protector y su comunicación a este instituto de las Bellas Artes. Sin embargo, en las actas de la junta particular del 10 de diciembre de 1769 el secretario Ignacio de Hermosilla informa que hizo presente una carta de la Real Academia de San Carlos de Valencia, fe-

${ }_{25}$ Informe de Pedro Rodríguez de Campomanes, fiscal del Consejo de Castilla. Madrid, 10 de enero de 1769. A.H.N.: Consejos, leg. 2076, núm. 5. Lo publicó Juan Carrete Parrondo en «Pedro Rodriguez de Campomanes. Informes sobre la Real Academia de Bellas Artes de San Fernando", op. cit., R.I.E., 1977.

2.6 A.A.S.F.: $\operatorname{leg}:$ 28-1/2. Fechado en Madrid, 23 de febrero de 1770. 
chada el 23 de mayo de ese mismo año. Solicitaba que la junta interpusiera su autoridad con el fin de que se despachasen las consultas pendientes para arreglar la práctica de la arquitectura y de la escultura, que constaba fueron remitidas al Consejo. Los consiliarios encargaron al decano y al secretario que pidiesen al Conde de Aranda su despacho, así como que este último lo solicitase a los fiscales del Consejo ${ }^{27}$. Había, por lo tanto, un común acuerdo y los mismos intereses entre ambas Academias, que trabajaban conjuntamente para verlos realizados. La sombra de la de San Carlos se hace presente en la de San Fernando desde su creación, adquiriendo mucho protagonismo en todas las disposiciones sobre el control de las obras de arte que se dictaron entre 1768 y 1777.

El fiscal comenzó su dictamen indicando que consideraba tal asunto muy digno de la atención del Monarca y del Consejo, así como muy propio del celo de la Academia. Establecía, de esta forma, tres nexos de dependencia jerárquica correlativa, siendo el último, precisamente, este centro de las Bellas Artes, cuya única aspiración era vincularse directamente con el Rey, proyecto realizado en sus Estatutos.

La respuesta de Campomanes se inicia con una serie de ideas muy en consonancia con el pensamiento académico de la época, que es resumido aquí brevemente. Hay que recordar la vinculación del Conde de Campomanes con Mengs, Felipe de Castro y Ventura Rodríguez, así como con Jovellanos, lo cual testifica no sólo su conocimiento y plena asimilación del concepto artístico de la llustración, sino también del discurso ideológico de la Academia de la época y hasta de los problemas estamentales existentes en su seno ${ }^{28}$. Por ello no resulta extraño que sus nombres se mencionen en este dictamen como artistas de singular valía, a quienes se desea dar el máximo protagonismo.

Comienza, así pues, haciéndose eco de la pretensión de tal centro de obligar a los artífices a manifestar a la «policía pública» todos los diseños de las obras de consideración, que fueran a emprender, para que con tiempo se les advirtiera de los yerros del arte y de la deformidad, y procurar mejorar el gusto y la idea de la obra. Coincidía con él en el mal juicio que muchos retablos y portadas de edificios, construcciones por otro lado costosas y magníficas,

\footnotetext{
${ }_{27}$ Actas de la Junta particular del 10 de diciembre de 1769. A.A.S.F.: 121/3, fol. 391 anv. y rev.

${ }_{28}$ Sobre las relaciones existentes entre el conde de Campomanes y Jovellanos, Pedro González de Sepúlveda, Francisco de Goya, Antonio Ponz, Felipe de Castro, Ventura Rodríguez y Mengs véase: BeDAT, C., "La Real Academia de Bellas Artes de San Fernando (1744-1808)". Madrid, Fundación Universitaria Española - Real Academia de Bellas Artes de San Fernando, 1989 , págs. 185 y 231.
} 
proporcionaba al carecer de proporción y gusto, lo cual demostraba la ignorancia del profesor, haciéndose, así, poco honor a la Nación. De este modo Campomanes certificó el nexo existente entre estética clasicista y economía.

El escrito fiscal también coincidía con la Academia al afirmar que el buen gusto no consistía en la multiplicación de adornos. Lo definía en su respuesta como la «sencilla y mutua concesión de las partes proporciones» según unas reglas fijas, trasluciéndose aquí las ideas de Mengs, que están presentes en todos sus conceptos estéticos. Los ignorantes, desconociéndolas, consideraban que tales normas se reducían a esa multiplicación de ornatos.

La única forma de llenar el Reino de personas capaces en la práctica del arte era la de examinar y calificar a los artistas de mejor gusto con una previa instrucción en las Escuelas de Bellas Artes. Estos discípulos serían los encargados después de difundir las ideas sencillas y nobles, y proporcionadas a los modelos, suministrados por la viva representación de la naturaleza o las comprobaciones dejadas por los maestros acreditados. Campomanes, como hombre de la llustración, creía ciega y racionalmente en la enseñanza como forma principal de progreso y de transformación de la sociedad. Es el momento de la gran reforma educativa española después de la expulsión de los jesuitas en 1767, período que se extenderá hasta 1789 bajo los preceptos de uniformidad y universalismo ${ }^{29}$. La influencia de Mengs se percibe en la idea de seguir los modelos de los artistas acreditados.

Se diferenciaba en este escrito, haciéndose también eco del pensamiento clasicista de la época, entre la ejecución y la idea, que podría ser deforme por la falta de una teoría e imaginación acostumbrada a lo grande y lo sublime, aunque los arquitectos y escultores supieran levantar un edificio o un retablo con mucho primor en la realización. Por este motivo indicaba que se necesitaban en España mucho menor número de grandes maestros que de operarios primorosos, concepto en el cual precisamente insistiría después, ya en 1781, un arquitecto tan significativo en la arquitectura española de la segunda mitad del siglo XVIII como era Juan de Villanueva ${ }^{30}$. En la respuesta fiscal se distinguía, así pues, entre los in-

${ }^{29}$ Estudio introductorio de José E. García Melero al «Discurso crítico-político sobre el estado de Literatura en España y medios de mejorar las Universidades y Estudios del Reyno". Madrid, Fundación Universitaria Española, 1974. Este documento, existente en el Archivo del Conde de Campomanes, resume el estado de la enseñanza en España por estos años de 1767-1769. Es muy posible que se deba al propio Campomanes.

${ }_{30}$ Sobre este asunto véase mi estudio titulado «El debate académico sobre los exámenes para las distintas profesiones de la Arquitectura (1781-1783)». (El arquitecto según Juan de Villanueva). Espacio, tiempo y forma, serie VII, núm. 6, 1993, págs. 325-378. Madrid, Facultad de Geografía e Historia. U.N.E.D. 
ventores y los ejecutores de las obras. Los primeros deberían ver y corregir los defectos advertibles en las plantas o alzados, que se les presentase, mientras que no se debía dar la calidad de inventores a los segundos por estar dedicados simplemente a copiar.

En este escrito se quería dejar muy claro que el Consejo ya estaba ejerciendo desde hacía cierto tiempo este control en la práctica artística y de una forma especial en las obras públicas de puentes, caminos y calzadas, que se le había encargado por una serie de leyes del Reino. Asumía en un principio la idea de gestionar administrativamente todo este proceso de inspección. Este organismo político desempeñaría el papel burocrático de centro receptor de los diseños de los proyectos; pero después los remitiría a los maestros más acreditados y célebres para su reconocimiento y aprobación, al mismo tiempo que les enviaría la descripción tópica del paraje, en donde se construiría. Es más, se dice específicamente en la respuesta fiscal que el Consejo ya había puesto en práctica el reconocimiento y el examen de los diseños en las obras hidráulicas con la supervisión de Marcos Vierna y en las de arquitectura civil con la de Ventura Rodríguez, entonces maestro mayor de Madrid. Se remitían a ambos cuantos planos se levantaban en el ámbito del Reino para las muchas obras públicas, que se construían de cuenta del común. De este modo, todos los maestros de provincias venían a ser una especie de aparejadores sliyos, formándose al mismo tiempo por medio de las correcciones e instrucciones de ambos. De aquí el gran protagonismo asumido por Ventura Rodríguez en la década de los años sesenta no sólo como proyectista de obras propias sino de control de otras ajenas.

En dicha respuesta se partía de una serie de hechos ya consumados, que, como primeros principios, quitaban responsabilidades a este organismo. Se indicaba que, aunque la escultura, la pintura y el grabado, como artes del adorno, pertenecían a las obras propias del común, no se recurría nunca al Consejo. Los cabildos, las parroquias, los conventos y los particulares ricos, así como los impresores y los autores de los libros, eran quienes empleaban a los artistas sin acudir a consultar ni a este organismo ni a ningún otro tribunal. Todo se trataba siempre privadamente. Era, por lo tanto, la mayoría de las veces el mal gusto del dueño de la obra el origen de las deformidades, que se advertían.

El Conde de Campomanes coincidía con el espíritu de la Academia en la idea de que el gobierno debía prescribir precauciones para controlar las reglas del buen arte en las obras. Y había que actuar así, aunque se contradijera la libertad del dueño en disponer de sus caudales como gustase. Era prioritario, por lo tanto, por importar a la república, el que nadie abu- 
sase del ornato excesivo, lo cual formaba parte del fomento de las artes. Interesa aquí destacar la prioridad que el fiscal dio en este caso a lo colectivo sobre lo particular.

No obstante, el plan fiscal de 1770 del Consejo, aunque participaba de la misma idea de control y de las inquietudes estéticas de la Academia, contradecía de un modo sangrante a este organismo en un punto muy importante y, en especial, sensible, de su representación de 1768: en su capacidad exclusiva de decisión total en el campo de las Bellas Artes. Este centro docente no quería de ninguna manera perder su propia autonomía, concedida por el Rey, bajo las redes de los complejos entramados político - administrativos del muy poderoso Consejo. La Academia tan sólo dependía de las decisiones reales y tal organismo quería controlarla, atarla, a través de un complicado sistema burocrático.

Había, así pues, un grave problema de competencias políticas. La respuesta fiscal del Consejo a la representación de los consiliarios de 1768 aceptaba el control poético en España de la práctica artística por parte de la Academia de San Fernando; pero la centralización de los diseños de tales obras de arte se realizaría siempre pasando primero y por último a través suyo. Campornanes estableció, así, una dualismo diferenciador entre las funciones de policía y burocrática del Consejo, y la esencialmente estética de la Academia, que quedaba siempre subordinada de este modo a aquel organismo de una forma política-administrativa.

La respuesta era, paradójicamente, tan sencilla en la apariencia como dificultosa en la práctica: el Consejo y la Academia controlarían conjuntamente los diseños. Al primero le correspondería la gestión administrativa; a la segunda su valoración poética. Había una gran lógica en esta decisión tan racionalista y tan borbónica. Así, los dueños y los artífices de las obras deberían presentar los proyectos al Consejo. Este organismo los remitiría después a la Academia, en donde se nombraría un revisor o revisores para estudiarlos detenidamente, quienes cobrarían un honorario «moderado" por esta labor, que debía figurar al pie del proyecto; pero nunca se podrían exigir derechos algunos para su Secretaría. Una vez informados serían devueltos al Consejo, a fin de que se diera la licencia oportuna para ejecutar la obra.

Pero, además, el dictamen fiscal establecía otras normas más particulares, que le inmiscuía de lleno en las competencias propias de la Academia. De esta forma, decidió la conveniencia de nombrar revisor al profesor más excelente en su Arte. Pero entrometiéndose aún más, opinaba que los mejores eran entonces Rafael Mengs, Felipe de Castro y Antonio Prieto - los dos primeros amigos personales de Campomanes y 
defensores del gobierno de la Academia por parte de los artistas- respectivamente en pintura, escultura y grabado. No se aludía a ningún arquitecto, tal vez, porque se pensase, que Ventura Rodríguez, también relacionado con los lazos de la amistad con el fiscal, y Marcos de Vierna ya se ocupaban de la arquitectura e ingeniería desde hacía algún tiempo y eran autosuficientes. Además, el arquitecto estaba directamente vinculado con la Academia, aunque sus relaciones con los consiliarios en este año conflictivo no fuesen precisamente las mejores.

Estableció, así, en cierta manera un parangón entre el pasado con toda su referencia de prestigio y el presente al comparar a aquellos con Juan Bautista de Toledo, Pedro Berruguete y Juan de Herrera, quienes ejercieron por disposición real el control sobre la arquitectura y la escultura en tiempos de Carlos I y Felipe II. Tales artistas habían hecho florecer el arte de esta época como nunca había sucedido en España, porque todos los demás habían seguido los planes de tan grandes maestros. Las obras existentes en Toledo, Granada, Segovia, Valladolid y otras partes del Reino demostraban, que habían cumplido los proyectos de tan grandes maestros, reinando así el buen gusto.

Todos los demás artistas del Reino estarían obligados a consultar, por lo tanto, a Mengs, Castro y Prieto sus ideas y planes, sin poder ejecutarlos hasta que no obtuvieran su aprobación. Los diseños se expondrían al llegar a la Academia durante una semana, para que los demás profesores y los discípulos pudieran poner los reparos y manifestarlos al primer profesor, dándole así luz a la hora de hacer las advertencias. Éste dispondría de los otros ocho días siguientes para reconocerlos y redactar el correspondiente informe. Se admitía, pues, un asesoramiento colectivo; pero la decisión final se individualizaba en estos cuatro artistas.

Pero, contradiciendo abiertamente el espíritu colectivo académico, el dictamen fiscal negaba la competencia global de la Academia de ser juez al estar ambiguamente compuesta por personas no facultativas en clara alusión al estamento directivo de los consiliarios, y otras pertenecientes a distintas profesiones. De aquí que se pueda intuir las influencias de Mengs y de Castro en la respuesta fiscal, quienes deseaban una Academia gobernada por los aristas al modo italiano y contra el sistema francés. Esta diversidad impedía el juzgar con la unidad requerida las diferentes partes, de que consta todo proyecto. Resultaba preciso impedir el inconveniente de tan variadas opiniones, aún entre los que eran personas pertenecientes a una misma profesión, que originarian una gran tardanza en las resoluciones, debilitándose lo sublime al darse «pinceladas» procedentes de diversas manos. Aquí, en oposición con la idea expuesta antes de la importancia de la educación estética 
de la mayoría frente al interés y libertad particular del dueño de la obra y del artista, invertía los términos: favorecía ahora el juicio individual de valor de un profesional destacado frente al colectivo de la Academia como corporación, cuya función quedaba relegada a un simple asesoramiento.

Una vez más estos conceptos parecen obedecer a los deseos existentes en el estamento formado por los artistas de autogobernarse frente al otro estrato directivo constituido por los consiliarios. $Y$ de nuevo hay que vincular a Campomanes con Mengs, quien en estos momentos ponía en tela de juicio la capacidad estética de los nobles de la Academia, el brazo aristocrático y político, nexo e intermedio entre los profesionales y el Rey. Así, durante este mismo año de 1768, tan interesante como conflictivo en este centro, el pintor era controvertido en las distintas juntas particulares por sus juicios disidentes. En febrero de 1768 se había negado a acudir como primer pintor de Cámara a dar clases de Anatomía a la Casa de la Panadería, programa propuesto por él en 1766 y aprobado por real orden ${ }^{31}$. Mengs, académico de honor, deseaba alcanzar entonces la categoría de profesor director. Estaba, además, ofendido porque la Academia había logrado una Real Orden por la cual los pintores, que gozaban de sueldo de S. M., acudieran gratuitamente a dar clases en este centro $\sin$ los honores propios del instituto...

De esta forma se atribuía en todo a la Academia una finalidad eminentemente pedagógica: la enseñanza de la juventud en el arte. Ello era posible, porque se podía distribuirla de manera metódica entre los diversos profesores. Pero «la formación de las obras, o el arreglo de los planes consiste en una idea sencilla y viuda que siempre debe fiarse al más célebre Profesor del Arte". Una opinión muy en consonancia con el despotismo ilustrado de la época y que premiaba cierta aristocracia intelectual.

La respuesta del Consejo parece obedecer a un doble interés: deseaba ejercer el control administrativo de las obras de arte; pero también parecía querer beneficiarse económicamente de una forma directa o indirecta al imponer al dueño de la obra o al artífice un gravamen, que hasta entonces nunca había tenido, al presentar los diseños y al pedir la expedición de la licencia a través de los escribanos de Cámara, quienes, así, obtendrían sus derechos. No obstante, para beneficiar de algún modo a la Academia, y evitar, así, sus protestas, también establecía que el revisor de los dise-

\footnotetext{
31 Las exposiciones de Mengs por las que rehusó dedicarse a la enseñanza de la Anatomía - disciplina cuyo estudio se impuso en este instituto por indicación suya - en la Sala de juntas de la Casa de la Panadería durante una semana por curso, ayudando a Agustín Navarro, director de esta disciplina, se hallan en A.A.S.F.: C.F. 2/4. Están fechadas el 1 y 2 de febrero de 1768. La invitación de la Academia para que se dedicara a esta tarea la firmó el secretario Ignacio de Hermosilla el día 1 de ese mes. El marqués de Grimaldi insistió el 9 de febrero.
} 
ños cobraría un «moderado» honorario con la finalidad de que no malgastara su tiempo en un trabajo tan útil, honorario que el profesor revisor indicaría al pie del proyecto censurado...

Se disponía, asimismo, en este dictamen fiscal la conveniencia de nombrar a un segundo profesor para que le sustituyera en sus ausencias y enfermedades. También, se indicaba que se debía depositar en la Academia un plan o modelo, para que con el tiempo tal corrección fuera un registro puntual de las obras más excelentes del Reino.

Lógicamente se debía prevenir de todo esto no sólo a la Academia, sino también a los corregidores, prelados, eclesiásticos, cabildos catedralicios y de colegiatas, y a los superiores de las ordenes a fin de que se observaran tales disposiciones en sus obras respectivas. Todo lo cual se haría por medio de una provisión circular. Así se actuó políticamente después, ya en 1777 .

La respuesta fiscal también se hacía eco del problema manifestado por los consiliarios del gran consumo que los artífices constructores de los retablos y de las estatuas hacían de la madera y del oro. Se deberían reducir todos ellos al empleo del estuco y de la piedra, calificados de ser los más permanentes y vistosos, siempre y cuando estuvieran ideados con el empleo de las reglas del buen gusto. De nuevo se establecía una correlación entre clasicismo y economía.

Para remediar tal abuso se impondría como pena el perder el importe de la obra toda persona que diese a hacer o hiciera de este modo sin atender a las nuevas normas. La multa serían impuestas por las juntas territoriales como asuntos de policía, quedando a su cargo también la inspección del cumplimiento de tal reglamento. Los fiscales pensaban que esta labor era muy distinta del ejercicio del mismo arte e impropia de un cuerpo destinado enteramente a la enseñanza de las tres artes. Así, se apartaba a la Academia de tal actividad por estos motivos y porque de otorgársela tal responsabilidad "declinaría en una especie de fuero privilegiado nutritivo de diferencias».

Es de destacar aquí como en la respuesta fiscal parece que se trata de exceptuar siempre a la arquitectura de todo este proceso de control académico al no ser mencionada abiertamente y al atribuirse a la Academia tan sólo el examen de las esculturas, pinturas y grabados. El control de este arte es de hecho implícitamente reservado al Consejo en virtud de una tarea que ya se estaba realizando de alguna forma por medio de Ventura Rodríguez, vinculado a la Academia como director de arquitectura y arquitecto de confianza tanto del Conde de Campomanes como del mismo Consejo, y Marcos Vierna. Es perceptible también que en este mo- 
mento, entre 1768 y 1770, la misma Academia no se atreve a solicitar abiertamente el control de las obras públicas arquitectónicas, sino sobre todo de las escultóricas: de los retablos - de gran interés al ser el lugar de encuentro en algo ambiguo entre los distintos artistas-y de las portadas de los edificios, para las que estaban trabajando tanto los escultores como los arquitectos, dado el sistema barroco decorativo imperante.

\subsection{El informe de Campomanes del 1 de marzo de 1769}

Pedro Rodríguez de Campomanes, fiscal del Consejo de Castilla, también respondió en un informe la consulta de la Academia del 20 de diciembre de 1768. La consideraba como una secuela de su representación del 4 de dicho mes, ya contestada por él el 10 de enero de 1769. Por ello reincide, aunque con más brevedad, en muchos de los aspectos antes indicados. La respuesta fiscal es una clara denegación de las pretensiones de los directores de escultura de examinar a cuantos escultores profesaran esta facultad y de controlar cuantas obras escultóricas se realizaran en el Reino desde este instituto. Además, se establece de nuevo una clara división de funciones a juicio de Campomanes entre el Consejo, al que correspondía la policía de las Bellas Aites, y la dirección de las obras públicas, guiada de la pericia de los profesores más distinguidos, y la Academia, encargada de su enseñanza... Se razonaba la conveniencia de no distraer a este organismo de su función pedagógica, mezclándola en el control de las artes.

En la respuesta fiscal se refleja la réplica razonada de los facultativos de este arte del 30 de diciembre de 1768. De aquí que fuese justificada la desaprobación de la propuesta académica de examinar a cuantos ejercieran la práctica de la escultura por la existencia de escultores, tallistas y retablistas antes de que se erigiesen las Academias de las Artes en Madrid y Valencia. A lo cual se añadía otro motivo: la falta de tales establecimientos en el resto del Reino, lo que imposibilitaba la mayoría de las veces la concurrencia a instruirse en ellas. Pero también ponía en duda la posibilidad de discernir entre los verdaderos escultores, y los tallistas y retablistas. Todas las obras no se podían pagar suficientemente. Tampoco era justo que las Academias interviniesen en los ajustes contra la libertad y arbitrio de los dueños de las obras. El fiscal hacía gala de un gran liberalismo económico, aunque en el dictamen anterior también hubiera puesto en duda el buen gusto de los mecenas, coincidiendo en ello con el instituto de las Bellas Artes. Además, la inconveniencia de obligar a hacer este examen era justificada por el hecho mismo de no haberlo realizado hasta entonces una gran parte de esos profesores. Asimismo, tal prueba demostraría que los 
maestros flaqueaban más en la teoría que en la práctica, pudiéndose suplir aquel defecto por medio de la revisión de las obras. No era justo privar de su industria a estos profesores prácticos. Campomanes, defensor de la promoción de la industria popular, pensaba que la ausencia de una formación teórica era una carencia generalizada padecida por el Reino hasta entonces. La falta debía remediarse sin perjuicio suyo por medio del cumplimiento de providencias fáciles, como las que proponía.

De nuevo distinguía en la realización de toda obra entre la invención y el diseño, y la ejecución de manos, entre los aspectos teóricos y los prácticos. Para la primera pensaba en la conveniencia de que existieran buenos directores generales. Su función sería la de ver y corregir los diseños con la finalidad de desterrar la barbarie existente, de la que la Academia se quejaba con razón. Sin embargo, el fiscal creía que para la ejecución de las esculturas se podía acudir tanto a los profesores como a los aficionados. La inspección de la invención debía correr a cargo del mejor profesor de cada ramo. Recordaba que en su informe del pasado 10 de enero había propuesto a Francisco Prieto para la dirección de las medallas y a Salvador Carmona para la del grabado por las diferencias existentes entre cada ramo y la excelencia respectiva de los dos profesores.

Recomendó, asimismo, la oportunidad de que cada uno de estos revisores escribiese unas instrucciones y unos elementos, que podrían ir juntos. Las primeras serían unas advertencias sobre los abusos que se hubieran observado en su profesión, sirviendo de guía a todos los individuos y de gobierno en sus obras. Se indicaría en ellas cómo debían venir los diseños a revisión. Los elementos o instituciones motivarían una enseñanza con gusto y uniformidad, promovida por los maestros más excelentes.

El fiscal indicó que, una vez aprobadas estas disposiciones por el Rey, las obras principales se expondrían en las Academias de las Artes con la finalidad de que tanto los profesores como los alumnos pudieran observarlas y proponer los reparos, que sirvieran de luz al revisor. También propuso que se hicieran copias de estos modelos y diseños en tales institutos de las Bellas Artes. Quedarían allí depositados, sirviendo de ejercicio práctico a los discípulos y maestros. Así, con el paso del tiempo se formaría una colección de las principales obras del Reino.

\subsection{La opinión de la Academia sobre el dictamen fiscal}

Era manifiesto que la Academia no podría conformarse con tal dictamen fiscal, que contradecía y perjudicaba seriamente tanto su autonomía 
como la intención de controlar institucionalmente la práctica artística del país. Las guerras abiertas, o clandestinas, entre el Consejo y este centro para asumir competencias en las Bellas Artes fueron continuas a lo largo de estos años, tal y como lo habían sido antes, y casi siempre por la fiscalización de la arquitectura, el arte más interesante de todos debido a su carácter práctico y a su misma cotidianidad. Tampoco gustaría a ese organismo el grado de independencia de la Academia y su vinculación directa con el Rey a través del protector, el primer secretario de Estado. De esta forma, la historia de sus relaciones tuvo siempre un componente escabrosamente complejo.

Así, alguien que firmó una carta dirigida a Iriarte y sin fecha, pero posiblemente escrita en marzo de 1770, bajo el título de Abate -en este momento había varios en la Academia, pero quizá se trate del mismo Ignacio de Hermosilla, su secretario ${ }^{32}$-, denunció tal respuesta fiscal, analizándola con ingenio agudo y con toda minucia ${ }^{33}$. Su opinión no era individual, pues obedecía al sentir colectivo de este centro de las Bellas Artes y especialmente al de su estamento rector, los consiliarios, que habían salido bastante mal parados en dicho dictamen al negárseles de una forma abierta su capacidad estética para juzgar las obras de arte. De nuevo la sombra de Mengs.

Trataba de hallar, además, con esta misiva una postura y un apoyo políticos, y también una solución adecuada ante estas injerencias del Consejo, al que el fiscal había confirmado su papel de policía de las Bellas Artes, bajo la protección de la autoridad prestigiosa de un Iriarte, su amigo e interlocutor, quien debía informar al Marqués de Grimaldi sobre el particular ${ }^{34}$.

Tal personaje, el abate firmante, era consciente del problema planteado en todas sus dimensiones. La creación de la Academia de San Fernando había quitado el poder exclusivo de decisión y de control del Consejo sobre las Bellas Artes, capacidad que todavía entonces este organismo estaba ejerciendo de alguna forma. Aquel centro tenía unos

32 Ignacio de Hermosilla y Sandoval, académico de número de la Real Academia de la Historia, fue nombrado secretario de la de San Fernando el 14 de noviembre de 1753. Le sucedió Antonio Ponz el 1 de septiembre de 1776. A.A.S.F.: Libro de protectores, viceprotectores y secretarios: $13 / 3$.

эз La carta del Abate a Iriarte, sin fecha, la he hallado en A.A.S.F.: leg. 28-1/2. Es un borrador o una copia.

34 Gefónimo GrimaldI, Marqués de Grimaldi, primer Secretario del Despacho Universal de Estado era protector de la Academia desde el 18 de diciembre de 1763. Nació en Génova en 1720 y murió en 1786 A.A.S.F.: $13 / 3$. 
Estatutos, que lo vinculaban directamente con el Rey en una época absolutista y lo daban una autonomía importante, no dependiendo políticamente de este organismo para nada. Era difícil que el todopoderoso Consejo se resignara en ese momento a perder en su totalidad tal control sobre la práctica artística y de forma especial sobre las obras públicas. Hallaría los mejores aliados en los antiguos maestros de obras, ahora marginados por la Academia por no haber pasado los correspondientes exámenes que confirmaran su título académicamente, desvinculándoles, así, del componente gremial. Pero no hay que olvidar que el Consejo contaba además con una serie de artistas importantes, como Ventura Rodríguez, Mengs, Prieto y Castro, dentro de la Academia, que no veían con malos ojos ese control de tal centro de gobierno frente a ésta, gobernada por los nobles, quienes les relegaba a un papel secundario y docente. Quizá este debate fuera en última instancia una muestra más de la lucha entablada en la época entre una Monarquía, que quería ser plenamente absoluta, y un sistema de gobierno heredado de la anterior dinastía, cuya representación máxima se hallaba en el Consejo.

Pero, paradójicamente, todo hace sospechar que el Consejo, a través de su fiscal Campomanes, tuviera también aliados dentro de la Academia, como podrían ser el academicista Mengs, ahora disgustado con los consiliarios de la junta particular de este centro, y el propio Ventura Rodríguez, que en estos momentos sostenía turbias disputas con Diego de Villanueva con motivo de las mediciones de los machones del templo de San Francisco el Grande ${ }^{35}$. El mismo Diego de Villanueva estaba resentido porque su libro había sido desacreditado en la junta particular de consiliarios, prohibiéndosele hacer uso del titulo de director de arquitectura de la Academia ${ }^{36}$. Uno y otro, Mengs y Rodríguez, se vinculaban con Campomanes asistiendo a sus tertulias. El arquitecto, entonces director general de la Academia, no había obedecido precisamente en 1768 las ordenes de la junta particular de este centro de las Bellas Artes de redactar un

35 En este sentido puede verse el libro de Alicia QUINTANA MARTíNEZ, «La arquitectura y los arquitectos en la Real Academia de Bellas Artes de San Fernando (1744-1774)". Madrid, Xarait Ediciones, 1983. Sobre el tema de las disputas de Ventura Rodríguez y Diego de Villanueva: págs. $52-60$.

36 Libro primero de las actas de la juntas particulares. (1757-1769) A.A.S.F.: 3/121, fol. 353 rev.. Aquí se lee lo siguiente: «El Señor Don Pedro Martín Cermeño vistos los tratados que quiere imprimir Don Diego de Villanueva, cuyo examen se cometió a su Secretaría en junta ordinaria próxima, informa que no los halla dignos de imprimirse con el título de Director de la Academia, y sin embargo de que la junta, no quería admitir pruebas de la justicia de este dictamen, el Sor. Don Pedro a mayor abundamiento leyó varios parajes en ellos que califican la prudencia y acierto de su opinión. En cuya consecuencia la junta acordó prevenir a Villanueva, que por justas causas no se le concede la licencia para usar el título de Director de la Academia en la impresión de dichos tratados". 
informe sobre los abusos que se estaban cometiendo en la práctica de la arquitectura ${ }^{37}$. Rodríguez tal vez estaba realizando una doble política con la Academia, en donde era director de arquitectura, y con el Consejo, para el cual censuraba obras públicas arquitectónicas. ¿Cómo iba a informar entonces sobre los abusos gremiales, de alguna forma consentidos por ese órgano político superior sin contradecirse y comprometerse? Si ese instituto se hacía con la censura de las realizaciones arquitectónicas, tendría que compartir una labor, que hasta entonces estaba realizando en exclusiva, con otros arquitectos académicos dentro de la Academia. EI mismo Campomanes decía en su informe de 1769 lo siguiente: «los Maestros Provinciales vienen a ser como una especie de aparejadores de Vierna y Rodríguez, y se van formando a fuerza de correcciones e instrucciones derivadas de estos célebres Profesores" ${ }^{38}$. Ventura Rodríguez debía al mismo tiempo «nadar y guardar la ropa». Existían, así pues, muchos intereses personales y colectivos contrapuestos, y bastante descontento de algunos de los principales artistas con los consiliarios, además de rencillas intestinas entre ellos, de las que el elemento nobiliario y directriz se aprovechaba.

El abate en su carta a Iriarte - Juan o, tal vez, ya Bernardo- denunció tal respuesta de Campomanes, analizándola con todo detalle. La consideró inconveniente por pesar económicamente demasiado sobre el dueño de la obra o el artífice y también inadecuada por complicar y rentilizar mucho el proceso administrativo, por el que pasaría el proyecto para lograr su control efectivo. Pero su temor principal, su pánico, era que el Consejo gracias a este dictamen pudiera obtener una Real Orden, que le diera autoridad sobre la Academia, de la que entonces carecía, pues el gobierno y la práctica del Arte estaba enteramente fiados al protector y a los consiliarios, sin que los Estatutos le otorgaran la menor capacidad de intervención. La Academia se vinculaba, así pues, directamente al Rey a través de su primer secretario de Estado.

Este personaje anónimo, agudo político, puso el acento en su carta a Iriarte, en que lo propuesto por la Academia no gravaba económicamente ni al dueño de la obra ni al artífice, pues se examinarían los diseños sin ninguna carga $y$, además, sin que se ofendiera su justa libertad. También devolvería los proyectos informados en un breve tiempo, aprobándolos o mejorándolos, y de balde. El mecenas lograría, así, la ventaja de asegu-

37 «Libro primero de actas de las juntas particulares de la Real Academia de Bellas Artes de San Fernando (1757-1769)". A.A.S.F.: 3/121, fol. 251 vuelta.

зв A.A.S.F.: leg:: 28-2/2, fol. $1 \mathrm{rev}$. 
rarse el acierto y la regularidad de la idea; y se proporcionaría insensiblemente al público obras dignas de verse. Por si fuera poco, en nada de esto se perjudicarían las legítimas autoridades del Consejo. A lo cual añadía: «Antes bien, con todo se sirve al Rey y al público». Así, se insinuaba un sometimiento del Consejo a la Monarquía. Además, en un momento histórico como éste, el proceso administrativo, la burocracia, constituía, sin duda, uno de los poderes más efectivos y, asimismo, uno de los más temidos de todos.

En esta carta se califica a la respuesta fiscal de «rara», no respondiendo a la propuesta sencilla y bien intencionada de la Academia del 4 de diciembre de 1768, basada en la razón y la experiencia. Escribió que, aunque el Consejo convino en lo substancial con ella, no la adoptó, realizando a su vez seis propuestas: 1․ Que los diseños de las obras se presenten al Consejo. 2․ Que éste las remitiera a la Academia. 3‥ Que este centro nombrara un revisor o revisores de ellas. $4^{\circ}$. Que se les pagara un moderado honorario, anotado al pie del proyecto. $5^{\circ}$. Que no se exigieran ningún derecho para la Secretaría de la Academia. 6․ Que se devolvieran los diseños al Consejo para que este organismo diera licencia para ejecutar la obra. Quizá la más perjudicada fuera la Secretaría de este instituto y, con ella, él mismo.

Nuestro abate anónimo estructuró su carta en base al comentario de cada una de estas normas dadas por los fiscales. Así, pensaba que en la primera y en la última de tales propuestas se imponía al dueño de la obra $y$ al artífice un gravamen que hasta entonces no habian tenido. $Y$ todo ello no sólo al obligarles a hacer una presentación y pedir una licencia innecesarias, sino también al hacerles gastar dinero en una y otra diligencias, pues los escribanos de Cámara obtendrían sus derechos al no trabajar gratuitamente.

Sin embargo, la propuesta que le preocupaba más era, sin duda, la segunda, ya que con ella, al remitir el Consejo el expediente a la Academia, conseguiría una resolución Li Orden Real, que le daba autoridad para mandar en este centro, poder dei cual carecía hasta entonces. Pensaba que dicho organismo no podía ni debía meterse en el gobierno y la dirección de la Academia, ni en mandarla. Sus Estatutos no daban al Consejo ninguna capacidad de intervención, porque el gobierno de la práctica de las artes estaba confiado enteramente al protector y a los consiliarios. Además, en el caso de cometerse abusos se prevenía, que se recurriría al Rey por medio del primer secretario de Estado.

El abate denunciaba al Consejo por inmiscuirse en la capacidad de la Academia para otorgar títulos. Ello ocurría al enviarla continuamente ma- 
estros de obras y agrimensores, para que les examinara, de la misma forma que Juan Sacheti y Francisco Ruiz hacían antes de su fundación. Este centro de las Bellas Artes les recibía y examinaba sin ninguna demora por puro deseo de moderación y de servir al público, así como para que no se creyera que había en ella ningún espíritu de altanería. Sin embargo, el Consejo no admitía a los discípulos aprobados de maestros de obras o agrimensores por la Academia, cuando acudían a esa institución a pedir el título correspondiente con la certificación de haber pasado los exámenes.

El Consejo no les otorgaba el título, porque exigía el cumplimiento previo de un proceso burocrático tan complejo como lento y desesperante. Una vez más este organismo basaba todo su poder en el uso, y aún muchas veces en el mismo abuso, de los complicados entramados administrativos, que, además, de poder le proporcionaban ciertas ganancias. Sin embargo, la Academia nunca había pedido ni percibido ningún dinero por examinarle.

Así, el aspirante a alguno de estos títulos se perdía laberínticamente en un ir y venir casi ciego por el Consejo. En primer lugar, tal y como se indica en esta muy expresiva e interesante carta, debía otorgar un poder a favor de un procurador, quien daría un pedimento en nombre del pretendiente a fin de ser admitido a examen. Una vez notificado el deseo y concedida la gracia correspondiente, el escribano de Cámara extendía una certificación, insertando dicho pedimento y auto. El aspirante acudía a la Academia con todos estos papeles y después de haber dejado pagados los derechos correspondientes del procurador, del escribano y por el papel sellado. Sería examinado en una junta ordinaria de este centro en el caso de desear ser maestro de obras; pero el viceprotector o decano encomendaría esta prueba a un director de arquitectura, si aspiraba al título de agrimensor. En la Academia se le expedía una certificación en el caso de haber aprobado, sin que le costara nada todo ello. Después volvía al Consejo con su aprobación, expediéndosele sólo entonces su título o licencia para ejercer su arte, siempre y cuando hubiese pagado los derechos correspondientes.

También manifestó su ironía al referirse al favor que el Consejo hacía a la Academia, creyéndola digna, de confiarla la elección de los revisores de las obras. A lo que añadía: «Y seguramente haría justicia el Consejo, si creyese que, cuando la Academia va a los pies del Rey con negocios de su inspección, los ha mirado antes por todos sus lados, con honor y probidad, sin ambición, sin deseos de mandar ni de utilizar a sus dependientes, y $\sin$ fiar a los caprichos o ideas de ellos, sus resoluciones ni fundamentos de ellas". 


\subsection{La repercusión en la Academia de San Fernando del pleito del Gremio de Carpinteros contra los escultores de la Academia de San Carlos}

El complejo pleito promovido por el Gremio de Carpinteros de Valencia contra los académicos escultores de la Real Academia de Bellas Artes de San Carlos hay que considerarlo, sin ninguna duda, como la causa más inmediata de la redacción de las cartas circulares de 1777, que concedían a la Academia madrileña el control de los proyectos artísticos. Estas Reales Ordenes motivaron a su vez la fundación de la junta de Comisión de Arquitectura ya en 1786. Todo ello contribuye a certificar el origen eminentemente social de estas disposiciones. Las luchas judiciales, a veces demasiado duras y enrevesadas, de las Academias contra los gremios para conseguir el dominio total de la práctica artística tuvieron muchas veces más importancia que las mismas y sutiles consideraciones estéticas. Sin embargo, el tema de la depuración de las formas, la pugna contra el barroco para imponer un nuevo clasicismo, fue el motivo esgrimido - la otra causa muchas veces, quizás, más aparente que real- por los nuevos centros borbónicos de las Bellas Artes frente a estas asociaciones profesionales de artistas.

Dicho pleito fue tratado en varias juntas particulares de la Academia madrileña por su carácter de centro dependiente, modélico y originario de la de San Carlos, como las del 31 de enero, 4 de mayo y 1 de junio de $1777^{39}$. Ocupó de una forma especial a la reunión de consiliarios del 25 de junio de larga duración y de un notable interés por los asuntos estudiados en ella. Las actas de esta junta, redactadas por Antonio Ponz, explican con toda minuciosidad posible el problema, sus distintas fases, los diversos pasos seguidos y las disposiciones aconsejadas por este organismo, promulgadas después por el Rey Carlos III bajo su inspiración casi literal ${ }^{40}$.

Los orígenes de este pleito se remontaban al año 1776 en una serie de denuncias consecutivas de los escultores de la Academia valenciana contra el Gremio de Carpinteros por dirigir y hacer retablos sin estar en posesión del título académico. Ello ocurrió en las juntas ordinarias de la Real Academia de San Carlos de Valencia de los días 5 de febrero y 11 de marzo de $1776{ }^{41}$. A

39 A.A.S.F :: 3/123. Actas de las juntas particulares del 4 de mayo de 1777 , fol. 51 rev., y del 1 de junio de 1777 , fols. 53 rev. -54 anv.

${ }_{40}$ Actas de la junta particular del 25 de junio de 1777. A.A.S.F.: 3/123. Este asunto en fols. 55 anv. - 73 anv. El tema lo estudio basándome en las actas de esas juntas particulares de la Real Academia de Bellas Artes de San Fernando.

${ }^{41}$ Joaquín BÉRCHEZ, op. cit. «Arquitectura ...”, págs. 250-251. Las denuncias fueron presentadas por los retablistas titulados Vicente Esteve, Vicente Llácer, Manuel Estrada y Salvador Estrada. 
tales querellas siguieron otras judiciales de estos mismos artesanos contra los escultores académicos y sus aprendices como réplica al realizar obras de carpintería sin estar agremiados. El problema real se centraba en la competencia que mútuamente se hacían al no hallarse las funciones respectivas definidas con toda claridad, motivo de las disputas continuas ${ }^{42}$. La Academia había hecho del adorno un campo específico suyo al ser considerado como un ramo subalterno de las nobles artes; pero quedaba sin definir con total exactitud qué aspectos de la proyección y realización de los retablos correspondían a los arquitectos y a los escultores.

Pero el detonante de la polémica más importante fue la denuncia que el Gremio presentó en 1776 por medio de su clavario contra los escultores José Puchol, director de escultura, José Esteve, teniente, y Pedro Juan Guisant, académico de mérito, los tres individuos de la de San Carlos, por no haber pagado las contribuciones correspondientes a los maestros del Gremio de Carpinteros de Valencia. El alcalde del crimen, Juan Domingo de Ara, sentenció en el pleito contra ellos. Así, los obligó a rescatar su deuda, al considerarlos como tales artesanos contra el sentido de los Estatutos de este centro de las Bellas Artes y los privilegios concedidos por el Rey, o a renunciar en el plazo de tres días a los magisterios obtenidos en esa asociación profesional antes de erigirse la Academia. La denuncia se basaba en que realizaban obras de adorno, consideradas como campo específico del gremio, puesto que se atribuía a los escultores académicos el trabajo de las estatuas.

Los académicos valencianos renunciaron formalmente a su maestría gremial, pues pensaba que retenerla era contrario al honor de su noble Arte. Pero no pagaron las contribuciones, que debían desde que habían obtenido dicho título hasta entonces. En este sentido imploraron la protección de la Academia valenciana.

En enero de 1777 la Real Academia de San Carlos envió a la de San Fernando una representación, dirigida al Rey, que fue leída en la junta particular del día 31. En ella se explicaba lo sucedido hasta entonces y se

\footnotetext{
42 Joaquín BÉRCHEZ trata este asunto en su libro "Arquitectura y academicismo en el siglo XVIII valenciano", op. cit., en el capítulo 11, págs. 253-256. Se basa documentalmente en la "Colección de Reales Ordenes comunicadas a la Real Academia de San Carlos desde el año 1770 hasta el de 1828". Valencia, 1828 (Ed. facsímil, 1980), y de forma especial en la "Real Resolución de S. M. de 22 de junio de 1777, en que declara varios puntos y Privilegios concedidos a la Real Academia de San Carlos y sus Individuos, comunicada por el Excmo. Conde de Floridablanca, primer Secretario de Estado y del Despacho, y Protector de las Bellas Artes", incluida en esa "Colección...". También en TRAmoyeres, L., "Epistolario artístico valenciano. $D$. Antonio Ponz". En "Archivo de Arte Valenciano", 1915, págs. 38 y ss., 118-123; 1916, págs. 39 y ss., 105 y ss., y $156-161$.
} 
daba su versión sobre el problema, centrándolo en varios aspectos. En primer lugar, se opinaba que el privilegio de académico debía mantenerse con todo rigor, a fin de que se cumplieran los designios de Carlos III sobre los progresos de las Bellas Artes. Además, la posesión de este título suponía una virtual renuncia de los magisterios del Gremio, pues, al prohibirse por ley su incorporación gremial, o a otros oficios mecánicos, se les eximía de la deuda. También se hacía referencia al pleito acaecido el año 1768, fecha del nombramiento de Jaime Molins como director de escultura, lo que hizo que el gremio le privara de sus magisterios anteriores. Este privilegio se había observado desde la creación de la Academia, y se cumplió tanto en el caso concreto del citado Molins como en el de sus antecesores Luis Domingo e Ignacio Vergara.

Por todos estos motivos la Real Academia de San Carlos había acordado que Juan de Corveres, su presidente, presentara un exhorto al juez, tal y como hizo, citándole el privilegio XXX, número 6, de los Estatutos para que desistiese de lo actuado. Asimismo, se ofrecía, como corregidor que era de Valencia, a notificar al Gremio de Carpinteros, que en adelante no reconociese por maestro de su cuerpo a ningún individuo de la Academia y que no intentase acción o demanda contra ellos en otro tribunal, que no fuera la propia Academia. Se basaba para ello en el privilegio XXXI, número 14, de dichos Estatutos.

Sin embargo, el juez se negó a invalidar su sentencia por dos razones distintas. En primer lugar, porque la causa ya estaba contestada y puesta en estado de ejecutarse, pues los académicos no la había reclamado antes. Es más, la aceptaron al otorgar escritura de renuncia a su profesión de maestros carpinteros, reservándose al mismo tiempo el derecho, que pudiera pertenecer a sus hijos. Por este motivo no podía desistir del conocimiento de dicha causa sin perjuicio de su jurisdicción hasta ver ejecutada su sentencia, y ello, aunque los académicos quisieran repeler la instancia del gremio a «limite judicis» con un certificado del artículo XXX, número 2.

El segundo motivo estaba en la interpretación jurídica de ese mismo artículo por el juez, pues en su opinión tan solo se refería, a que ningún tribunal podía obligar a los académicos a incorporarse en gremios, ni sujetarse a cargas, repartimientos, etc... Caso distinto era, si ya pertenecían antes a él, puesto que, al haber gozado de los emolumentos y utilidades correspondientes, debían sufrir las cargas. Además, Ara pensaba que, los académicos no deberían haber recurrido a la junta, y que seguiría su resolución hasta el total cumplimiento de la sentencia.

El pleito se hallaba en esta situación, cuando la Real Academia de San Carlos escribió a la de San Fernando, para que intercediera ante Carlos III. 
Se deseaba que su representación al Rey tuviera el apoyo del instituto madrileño. Era preciso reparar el agravio sufrido y frenar al Gremio de Carpinteros de Valencia, "obstinado en incomodar a los Escultores y ocupar a la Academia». Esta asociación había obligado bárbaramente a tales artistas a incorporarse a él antes de la fundación de ese centro valenciano. Además, la Academia de San Carlos había ignorado el pleito hasta que los escultores le habían presentado un memorial. Sus consiliarios pensaban que la ignorancia o errada conducta de éstos no podían perjudicar los privilegios del cuerpo.

Antonio Ponz ya alude al contenido de la representación de la Real Academia de San Carlos al monarca fundador en las actas de la junta particular del 4 de mayo y del 1 de junio de 1777. También se refirió a los documentos relacionados con el proceso seguido hasta entonces, remitidos por ese instituto valenciano. En la junta del 4 de mayo se había acordado pasar al Protector la representación de aquella Academia. En la del 1 de junio se leyó una carta de éste, fechada el 21 de mayo, en la cual pedía el parecer de la de San Fernando.

En la representación de la Academia valenciana se pedía que el Rey se dignara mandar en vista de las razones expresadas que los escultores, por el hecho mismo de haber sido nombrados académicos, dejaran de ser maestros carpinteros. Por consiguiente, era ociosa y mal fundada la renuncia, que hicieron en virtud de la sentencia dada por el juez. También se rogaba que Carlos III se sirviera mandar a los gremios abstenerse en adelante de semejantes pleitos. La Academia se basaba en tales peticiones en su celo por el exacto cumplimiento de los Estatutos y privilegios concedidos. Por ellos se sostenía el honor y la libertad de sus profesores, separándoles de los mecanismos de los gremios. Todo ello se indicaba en el capítulo II de sus Estatutos. Ningún tribunal podía obligarles a incorporarse a ellos, a ser visitados y examinados por los veedores o síndicos, a pagar contribuciones, ni repartimientos. Además, hacía suyo el privilegio de la Academia de San Fernando, expreso en el artículo XXXIV, párrafo 15 de sus Estatutos. En él se reconocía la nobleza de las Bellas Artes y se declaraba que los individuos, que se incorporasen a alguno de los gremios, quedaban privados de los honores y grados académicos. Se hacía, así, incompatible el título y profesión de académico con el ejercicio gremial.

En la junta particular del 31 de enero de 1777 la Real Academia de San Fernando había acordado, que antes de acudir al Rey, el Marqués de Santa Cruz escribiera a Ángel Antonio de Figueroa, Regente de la Audiencia de Valencia. Le pidió oficialmente que tomase las providencias más oportunas, para que no tuviera efecto lo actuado por el juez Juan 
Domingo de Ara. Se le consideraba como incompetente en esta materia al haber procedido contra los Estatutos y los privilegios concedidos por el Rey, mandados observar al gobernador y ministros de su Consejo, a los presidentes, ministros y oidores de Cancillerías, Audiencias, etc...

El Regente contestó al Marqués de Santa Cruz el 19 de abril de 1777 relatándole la situación. Había enviado su carta de oficio al juez, al mismo tiempo que una copia, entregada por el Marqués de Jura-Real, académico honorario de la de San Carlos, del pleito mantenido en 1764 entre el académico Fita y el Gremio de Carpinteros de Zaragoza. Ara contestó a Figueroa con la misma respuesta dada a la Academia valenciana. Decía que, habiendo revisado el caso, se hallaba de acuerdo con la sentencia dada en su día. Pensaba que los motivos del pleito de Zaragoza eran distintos al de Valencia. Además, no tenía facultades para revocar, confirmar o anular sentencia ya pronunciada, asunto reservado a los tribunales superiores por vía de recurso o apelación. Consideraba que la única solución era la declaración del soberano sobre el particular.

Por tal motivo la Academia de Madrid decidió en la junta del 4 de mayo dar curso a la representación de la valenciana ${ }^{43}$. Así, la envió al Protector junto con otra suya, en la que se apoyaban las razones expuestas por este instituto. Pero entonces se recibió otra del Gremio de Carpinteros, enviada a Carlos III. En ella se pedía que se declarase pertenecer a sus maesiros el trabajo de todas las obras de madera, incluyéndose en ellos los retablos, canceles de la Iglesia, púlpitos, talla, ornatos y cuantas otras se ejecutaran en tal materia. Deseaban que se indicase que a los escultores académicos sólo los correspondía la realización de estatuas. Solicitaba, además, la facultad de poder denunciar a los contraventores y de hacerlos pagar multas. Basaban sus peticiones tanto en su existencia de más de tres siglos como en el hecho mismo de que, si no se actuaba así, se arruinaría el Gremio por falta de contribuyentes. Este escrito fue enviado por el Protector a la Academia de Madrid el 21 de junio para que informara sobre el particular.

Tal representación del Gremio de Carpinteros fue analizada en la junta particular de la Real Academia de San Fernando el 25 de junio de 1777. Entonces se acordó que el secretario Antonio Ponz respondiera al Protector en los términos señalados en dicha junta. Su texto, fechado el 2 de julio en estas actas, resulta algo desordenado y no está demasiado bien redactado, pues hay mucha reiteración de ideas y a veces poca claridad.

43 A.A.S.F.: 3/123, junta particular del 4 de mayo de 1777 , fol. 51 rev.. 
La base del discurso se establecía en la crítica a los gremios y en su comparación con la formación académica. El problema del instituto valenciano pasaba de ser particular a generalizarse en toda España. Ponz comenzaba afirmando que el escrito gremial era «la mejor prueba del deplorable estado a que las Nobles Artes habían llegado" antes de la fundación de las Academias por Felipe V, Fernando VI y Carlos III. Se indicaba que la actuación de estos maestros en las obras artísticas tan sólo había dado lugar a la realización de auténticas «monstruosidades», pues tan sólo correspondía su auténtica creación a los «grandes ingenios», que se habían cultivado en profundos estudios. En su opinión tal capacidad tan sólo la tenían los profesores de las tres Bellas Artes, examinados por las Academias. De aquí que a los académicos se los hubiese otorgado la «nobleza personal» y a los demás profesores, formados en ellas, una «entera independencia». Se establecía de nuevo, como en los siglos renacientes, la distinción entre las artes mecánicas y serviles, propias de los gremios, y las liberales, que encarnaban los profesores formados en el academicismo. En la contestación de la de San Fernando se calificaban a las obras realizadas por los gremios durante sus tres siglos de existencia como "partos más de la crasa ignorancia" de personas totalmente ajenas a las Bellas Artes, "costosísimas producciones", "objetos de indignación"... ${ }^{44}$ Además, se criticaba que la materia con que se realizara la obra de arte definiera la atribución gremial de la misma. Se indicaba que para realizar retablos se tendría que ser pintores, escultores y arquitectos, pues en ellos no figuraba más que arquitectura, escultura y pintura. Se hacía ver la sujeción de los artistas a tal Gremio, si se cumplían sus deseos indicados en la representación, rompiéndose con la libertad de las Bellas Artes. Asimismo, de aceptarse las peticiones gremiales el ingenio y la remuneración del profesor quedarían sujetos a la voluntad del carpintero. La realización de obras llanas e independientes del dibujo, como los bancos y otros utensilios de los templos, era tan solo la competencia de estos maestros, pues tanto en los canceles como en los púlpitos de las iglesias con frecuencia figuraba algún orden o porción de arquitectura, u ornatos y figuras arquitectónicas y escultóricas. De nuevo el dibujo, nexo entre las artes, era el lenguaje del artista. También, y esto es importante, se consideraba como el mayor empeño de las Academias el «aniquilar semejantes abortos del arte y, si es posible, quitarlos para siempre de la vista» ${ }^{45}$. No obstante, se dejaba abierta la posibilidad de incorporación de los maestros gremiales con talento y habilidad a la Academia siempre después de haber

A.A.S.F.: $3 / 123$, fol. 62 rev.

45 Ibidem, A.A.S.F.: 3/123, fol. 63 rev. 
realizado los exámenes correspondientes en ella. Se hacía hincapié en que condescender a las peticiones de dicho Gremio sería "perpetuar la ignorancia, el mal gusto y el desacierto en las obras públicas» ${ }^{46}$.

La parte final del texto redactado por Antonio Ponz aludía directamente al problema particular de la Real Academia de San Carlos de Valencia. Se denunciaba la guerra del Gremio de Carpinteros contra este instituto. Se hacía ver la oportunidad de su fundación para proteger a los arquitectos y escultores valencianos, y permitirlos el libre desempeño de su profesión. En su ausencia se vieron precisados a sujetarse a tal asociación para no ver embargadas sus obras. Sin embargo, una vez establecida, no se podía seguir soportando sus presiones, que se materializaban en el hecho mismo de pretender como suyas las obras pertenecientes a las Bellas Artes, citar a académicos ante jueces y presentar recursos contra la Academia ante el Rey, que la había fundado, para que apoyase sus pretensiones.

Las peticiones concretas de la Academia madrileña, basadas en los Estatutos y privilegios de ambos institutos, se concretaban en que se declarasen los retablos, púlpitos, canceles, proyectos de órganos y demás adornos de Iglesias como pertenecientes a las Bellas Artes. Los profesores académicos no podrían hacer de ellos las obras llanas, que corresponderían a los maestros del Gremio de Carpinteros. Los tallistas nunca se deberían contar entre dichos profesores sin que la Academia les reconociese por tales después de haber sido examinados y aprobados sin dispendio alguno. Por este motivo no debían ejecutar obras relativas a las Bellas Artes. En el caso se ser admitidos cesarían de pertenecer a dicho Gremio y estar libre de toda contribución, tal y como se indicaba en el artículo 30 de los Estatutos de la Academia valenciana y en el 34 de la madrileña.

El contenido de este informe, firmado por Ponz como secretario del instituto, se reflejó con gran fidelidad en la real resolución, que el protector Conde de Floridablanca remitió a la Academia de San Fernando y a través suya al Marqués Vaumark como Capitán General del Reino de Valencia, fechada en Aranjuez el 22 de junio. Se aceptaban los deseos de ambos institutos, al tiempo que se confirmaban los contenidos de los artículos antes indicados de ambos Estatutos. De esta forma, Puchol, Esteve y Guisant quedaban segregados e independientes del Gremio de Carpinteros desde el mismo día que fueron nombrados académicos, sin necesidad de hacer renuncia de sus magisterios y estando exentos de pagar contribuciones a dicho Gremio. Por tal motivo se les debía restituir las cantidades exigidas

46 Ibidem, A.A.S.F.: 3/123, fol. 64 rev.. 
por él. Pero el presidente de la Academia de San Carlos debería reprenderlos severamente por su comportamiento en una junta. Tal real resolución contestaba también a la representación del Gremio de Carpinteros de Valencia en los mismos términos fijados por la Real Academia de San Fernando. Relegaba su actuación a aquellas obras lisas y sin necesidad de dibujo.

La Academia madrileña envió el original de tal real disposición al Capitán General del Reino de Valencia y una copia a la de San Carlos. En una carta del 26 de junio adjunta se indicaba que al igual que los miembros de la junta habían celebrado la disposición regia, «les será extremadamente sensible que los profesores de la Academia de San Carlos den en adelante a los carpinteros el más mínimo motivo de queja, trabajando en obras particulares a su Gremio; y no solamente no entrará por ningún título en el empeño de defenderles, sino al contrario lo tomará muy grande para que los escultores u otros académicos, que tal hiciesen, sean excluidos de la de San Carlos, y de cualquier otra de las establecidas o que puedan establecerse en España" ${ }^{47}$. Se recriminaba a los tres académicos valencianos por haber antepuesto «su particular interés al honor de académicos». Se exponía que su comportamiento había sido «indecoroso a sus personas y privilegios, y al honor de la Academia».

\subsection{La representación de los consiliarios al Rey del 10 de agosto de} 1777

Los académicos de mérito por la arquitectura presentaron una memoria a la junta particular del 10 de agosto de 1777. En ella exponían los muchos daños, que las personas sin pericia ni estudio ocasionaban a la causa pública, al honor de la nación y al crédito de la Academia al encargarse de realizar obras públicas sin ningún decoro. Pero, aunque pareció que las razones dadas eran sólidas y bien fundadas, esa junta retrasó tomar providencias hasta que el Rey manifestase su intención sobre la representación, que los consiliarios, le presentaban. En ella se hallaban contenidos motivos idénticos, a los que los académicos de mérito habían manifestado en tal memoria ${ }^{48}$.

En esa misma junta se leyó la aludida solicitud, que se presentaría cuatro días después al Rey. ¿El estamento directivo y nobiliario se apropió de

47 Ibidem, A.A.S.F.: 3/123, fol. 71 anv. y rev.

48 Actas de la Junta Particular del 10 de agosto de 1777. A.A.S.F.: 3/123, fol. 89 rev.. 
las ideas de los arquitectos para asegurar su superioridad ideológica y jerárquica ante Carlos III, y probar a los artistas su subordinación, o existía un interés común por el estado de la arquitectura en España manifiesta en esos dos documentos de una forma totalmente sincrónica? Lo evidente es su estricto vínculo con las ideas ya manifiestas en los escritos de 1768 y la influencia, que los problemas habidos entre la Real Academia de San Carlos y el Gremio de Carpinteros de Valencia, ejercieron para reincidir en la petición de control de las obras públicas por parte de la Academia.

El empleo del recuperado lenguaje clásico, como propio del academicismo y en boga internacionalmente, era el medio más adecuado de la Academia en su lucha contra las viejas y trasnochadas estructuras gremiales, ancladas en el uso de ya viejas fórmulas barrocas ornamentales, de auténticas máscaras constructivas. De aquí que en esa representación se reincidiera en conceptos repetitivos a lo largo del último cuarto del siglo de la llustración contra esa tendencia. Se hacía ver que los edificios, no promovidos por el mecenazgo real o por la Academia, eran siempre «fábricas disparatadas». Se vinculaba su realización a la «ignorancia» de los proyectistas y constructores. El «racionalismo», el «orden», el «decoro»y la «economía» adecuada, por su calidad de postulados propios del resucitado nuevo clasicismo, eran comparados en la solicitud del 10 de agosto de 1777 con las ideas «frenéticas», los «despropósitos» y «borrones», el «gran desorden», los "objetos indecorosos y ridículos», el «desenfreno y licencia» y el «despilfarro» de ese barroco ornamental, no del estructural.

\subsubsection{Alabanzas al Rey: las obras reales como modelos del nuevo clasicismo}

Los consiliarios obviamente aspiraban en su escrito a conseguir la aprobación real de la propuesta académica. Para lograrlo ensalzaron unas veces de forma abierta y otras con alguna sutileza la vanidad de Carlos III a lo largo de todo el documento. Tales alabanzas se basaban en primer lugar en la idea de que el Rey sería recordado históricamente por las grandes empresas realizadas en obras públicas promovidas por su patronazgo personal. Por ello tanto España como de forma especial la Academia por su condición de instituto de las Bellas Artes, le debían reconocer -y de hecho le reconocían - como «el principal restaurador de la mejor y más arreglada arquitectura» ${ }^{49}$. Señalaban que ya durante su reinado napolita-

49 Ibidem, fol. 9 rev. 
no había alcanzado un gran prestigio, reconocido en varios escritos públicos, por «las útiles, magníficas y arregladas obras con que ennobleció la ciudad y reino de Nápoles" 50 .

Con la finalidad de silenciar cualquiera reticencia importante por parte del Rey se indicaba, que la propuesta de la Academia para remediar la situación, no podía encontrar ninguna «dificultad, resistencia, ni disgusto» por parte de las personas, a las cuales se hubiera de proponer. Pero también se trata de no crear ningún conflicto grave ni político ni en la misma conciencia religiosa de Carlos III por la necesaria intromisión suya y de este centro de las Bellas Artes en las construcciones y estética de la Iglesia. Así, se acude una vez más a su vanidad al motivarle para que pensase que el «remedio será tenido por uno de los más dignos de la Religión y piedad» del monarca.

De esta forma se establecía una comparación entre las grandes y bellas empresas reales y el desprestigio de esas «fábricas disparatadas", que ofendían estéticamente tanto al Rey como a la religión, a la «edad presente» y al «público». Al primero por afearle sus ciudades y Reino; a aquella porque se llenaban las iglesias de objetos indecorosos y ridículos; al presente debido a que se imprimían tantas y tan torpes huellas que lo desacreditaban, y, finalmente, a los vasa!los por un motivo educativo tan ilustrado, pues tantos ornatos en lugar de enseñarles a conocer y estimar lo bueno, le dejaban "con su ceguera y con la ridícula costumbre de apreciar lo malo».

Interesaba a la Academia insistir en que Carlos III tomara conciencia, o simplemente recordarle, de la ofensa que la inadecuada utilización de la arquitectura producía a Dios. Los consiliarios proporcionaban al Rey en su escrito una serie de motivos razonados para que pudiera entrometerse de forma justificada en las construcciones religiosas. Había que demostrarle, para que se valiera de tales raciocinios ante las autoridades eclesiásticas, que en los templos, como "casas de Dios» era necesario poner el mayor esmero para que cuanto hubiese en sus recintos fuera adecuado a la «Dignidad del Señor que alli se adora, fuente de toda sabiduría, de todo buen orden, grandeza y armonía» ${ }^{51}$. Pero también había que llamar la atención de Carlos III ante un problema, para el cual estaba ya especialmente sensibilizado: las iglesias eran en la mayoría de los casos los edificios más importantes de las localidades. Los viajeros al llegar a una ciudad visitaban en primer lugar su catedral y sus templos más importantes. La política urbanística, la decorosa y racional imagen de la urbe, cons- 
tituía una de las principales preocupaciones regias. De este modo la arquitectura religiosa se constituía en el más señalado centro visual de la ciudad, todo lo cual justificaba la intromisión real en asuntos eclesiásticos relacionados con la arquitectura de los templos.

Así, Carlos III debía ser el paladín, que impusiera el buen orden debido a su religiosidad y a su preocupación urbanística ante tantos despropósitos, pues desde hacía aproximadamente un siglo las catedrales y las iglesias más importantes de España se habían «afeado», y se había creado un auténtico "delirio" arquitectónico. Los templos madrileños estaban llenos de «borrones» y de «despropósitos», profanándose la religiosidad y su decoro.

Y nada parecía mejor para demostrarlo que acudir a la Historia como testimonio y cita tan del agrado de los ilustrados. Se establecía de nuevo un parangón, ahora entre tres épocas históricas distintas: los siglos del gótico, cuya arquitectura entonces se estaban revalorizando estéticamente aún produciendo contradicciones emotivas, los del Renacimiento, como restablecimiento del «más grandioso modo de edificar» y el último siglo, debido a la pérdida de la "buena escuela». Los consiliarios alabaron furtivamente las catedrales de Toledo, Burgos y León por su magnificencia, y porque «en aquella línea se consideraron maravillosas". La grandeza y el fino gusto constructivo renacentista se materializó en España según esta representación al Rey en El Escorial, el alcázar y el hospital de San Juan de Toledo, el palacio de Aranjuez y en el alcázar madrileño incendiado. Pero esta grandiosidad constructiva también se hallaba en la catedral de Valladolid, en las iglesias del Carmen y de San Jerónimo de esta misma ciudad, en la catedral, alcázar y Chancillería de Granada y en la lonja de Sevilla. De Madrid se señalaban la casa de los Reales Consejos, la cárcel de Corte y los conventos de San Felipe el Real, la Trinidad, la Encarnación y San Isidro. Los límites entre esta arquitectura regular y su desprestigio se establecían durante el reinado de Felipe IV, el antepenúltimo monarca de la anterior dinastía...

$\mathrm{Si}$ estos edificios se citaban como modelos de la buena arquitectura, otros realizados en época más reciente eran puestos como ejemplos de monstruosidades y de sueños disparatados: las fachadas del hospicio, de San Sebastián, de Santo Tomás, de la puerta de Atocha, de la Merced, de Porta Caeli y de Montserrat en Madrid.

\subsubsection{Los aspectos económicos de la representación}

Se quiso relacionar estrechamente el renacimiento cíclico de un nuevo clasicismo con la mejora de la economía constructiva durante el 
Orígenes del control de los proyectos de obras públicas por la Academia...

último tercio del siglo XVIII. La arquitectura era considerada una de las Bellas Artes más útiles y necesarias, pero muy costosa para el Reino, si las obras públicas no se realizaban con decoro, economía y racionalidad. La Academia se había propuesto demostrar al Rey que el empleo de un lenguaje formal desornamentado producía un ahorro considerable a medio plazo de tiempo tanto al Reino como a la Iglesia, aunque se utilizasen materiales constructivos en principio más caros aparentemente. Así se pretendía conseguir la aprobación regia de su propuesta de control centralizado de las obras públicas tan del gusto de los monarcas de la dinastía de los Borbones. La representación de los consiliarios del 10 de agosto de 1777 insistía de continuo en tal idea a lo largo del documento de un modo sutil, concepción siempre coincidente con el pensamiento de Carlos III. El monarca halló en el escrito académico una serie de motivos justificativos para decretar y realizar las pretensiones de la Academia.

Si el abaratar los gastos en arquitectura resultaba útil a fin de lograr la pretensión económica de control absoluto sobre las Bellas Artes, la idea también era importante para acabar con el barroco ornamental tan empleado por los practicantes gremiales y desprestigiarlos. El decoro y la economía de los edificios coincidían en el clasicismo. Por estos motivos los consiliarios se afanaban en demostrar que el mantenimiento de tal "aprobio», de la nación producía el consumo de «inmensos caudales» por todo el Reino.

Pero, asimismo, se trataba de conciencia a la Iglesia de la necesidad y utilidad de que la Academia controlase cuantas obras se hacían en sus templos para su propio beneficio. De nuevo se pretendía mentalizar al Rey en la idea de su imprescindible injerencia en los asuntos eclesiásticos, pues su devoción e interés le movían a preocuparse de que la Iglesia no derrochase inútilmente sus bienes en realizaciones sin el decoro necesario a la casa de Dios. Por ello se insiste en los «indecibles gastos» producidos por la multitud de fábricas sagradas realizadas por toda la Monarquía, en los «pinares sin número» de los retablos y en los «montes de oro» desperdiciados en la realización de «monstruosos adornos y altares», en «caprichos quiméricos"...

\subsubsection{El papel de la Academia}

Recordar a Carlos III el papel importante desempeñado por la Real Academia de San Fernando como instituto de las Bellas Artes y sus orígenes borbónicos también resultaba un aspecto esencial, que se incluia en 
la representación con el fin de conseguir la aprobación por el Rey de las disposiciones políticas solicitadas. Se insistía en los desvelos del centro por hallar los medios más adecuados para que la arquitectura alcanzase el «grado de representación» prestigioso que el mecenazgo del monarca le estaba dando. Los consiliarios manifestaron, sin embargo, su desengaño ante la insuficiencia de las distintas medidas tomadas hasta entonces para atajar tan gran desorden constructivo. Entre ellas se citaban diligencias pedagógicas, como eran los premios de la Academia, las pensiones en Roma y la adquisición de los mejores libros de arquitectura con la finalidad de facilitar su progreso. Pero también se indicaba en la representación el uso de los privilegios otorgados en competencias y disputas para que no se hiciesen las mismas extravagancias que antes.

Una vez más la historia, en este caso de la Academia, es empleada como cita demostrativa y modelo a seguir. Los consiliarios se apoyaron en su discurso en la idea de que el centro había sido una fundación específica de la dinastía de los Borbones, en la cual su padre Felipe $V$ y su hermano Fernando VI habían intervenido. Aquel la dio principio en una junta preparatoria, mientras que éste la dotó y concedió privilegios y leyes para su gobierno. Consideraban ese momento aún próximo en el tiempo como una época «feliz para las Artes». Con todo ello se deseaba comprometer a Carlos III, siguiendo los pasos de sus predecesores, para que decretase nuevas disposiciones con la finalidad de hacer más efectiva a la Academia.

\subsubsection{Los mecenazgos}

También era necesario definir en la representación los distintos mecenazgos de las principales obras públicas que entonces se realizaban en España: el real, el eclesiástico y el civil o estatal. Si el primero promovido personalmente por Carlos III, se proponía como modelo de decoro y regularidad, los malos ejemplos de aberraciones constructivas y de falta de economía eran localizados en los otros dos patronazgos. Pero, asimismo, aunque se quería demostrar al Rey que ambas especies necesitaban de un idéntico planteamiento de control centralizado desde la Academia, debían dárseles un distinto matiz expositivo y sutileza formal, para que se lograse el cumplimiento de las pretensiones académicas según se trataran de obras civiles o religiosas.

El mecenazgo de las construcciones eclesiásticas, a las que se dedicó mucha más atención en el documento que a las del Estado, pasaba a través de los reverendos obispos, los cabildos, los prelados y las comunida- 
des. El civil o estatal corría a cargo de los capitanes generales, audiencias, intendencias, ayuntamientos, corregidores y otros magistrados, sirviendo el Consejo de Castilla siempre de intermediario.

La existencia de estos dos tipos de obras eclesiásticas y civiles, y la incidencia indudable de aquellas últimas en la ciudad, obligaba a los consiliarios a proponer dos formas distintas de planteamiento del problema. Manifestaron una gran habilidad política que habría de ser grata al Rey, quien también debía considerarse capacitado para asesorar y servir de árbitro por su devoción religiosa y hasta por su calidad de monarca a la Iglesia en asuntos que afectaban al bien común. Por tal motivo aconsejaron a Carlos III la posibilidad de seguir sendos tipos de medios formales diferentes, pero complementarios en un mismo objetivo. Su finalidad era lograr que los proyectos de construcciones de importancia, tanto de las civiles como también de las religiosas, se remitiesen a la Academia en plano, alzado y corte para ser examinados gratuitamente y sin interés alguno. El instituto de las Bellas Artes expondría su opinión sobre la exactitud, los errores y los defectos de dichos dibujos para ser construidos con regularidad y razón. Determinaría si eran dignos de ejecutarse o, en caso de no serlo, se indicarían los medios más adecuados para lograrlo.

El doble destinatario, eclesiástico y civil, obligaba, por tanto, a asumir formalidades y tonos distintos: en un caso el ruego epistolar, en el otro la orden por medio de una Real Cédula. Carlos III habría de escribir a los reverendos obispos y cabildos para exhortarles a asumir esta disposición, mientras que a los magistrados, audiencias y ayuntamientos del Reino podría simplemente mandarles que se conformasen en la expresada providencia.

\subsubsection{Los materiales}

La otra disposición, que los consiliarios querían conseguir, era el logro de una ya vieja aspiración desde las representaciones de 1768: que los altares o retablos se construyeran $\operatorname{con}^{52}$ materiales nobles, que no fuesen realizados en madera. El motivo razonado se basaba en la fragilidad, su condición corrompible, la inadecuación a la dignidad del destino, su corta duración y la gran exposición a incendios. Pero con una gran modernidad se daba, además, otra causa, que en nuestros días sería calificada como

${ }^{52}$ Ibídem, "Representación...», fol. 14 rev. 
ecológica: se estaban destrozando gran cantidad de pinares con gran perjuicio para la Nación. También se ahorraría el enorme consumo de oro para estas realizaciones, que llenaban los templos.

Se proponía el empleo de los mármoles y del bronce como materiales más nobles, dignos y resistentes para la construcción de altares o retablos. La existencia de canteras cercanas a las ciudades del Reino propiciaba tomar esta medida, que terminaría de una vez para siempre con la mala usanza - considerada aquí como peculiar en España- de la utilización indiscriminada de la madera en tales menesteres. Y el modelo a seguir se hallaba, una vez más, en el mecenazgo real, pues Carlos III había enseñado el «verdadero y decente modo de fabricarlos, costeando muchos, y suministrando piedras y bronces para otros, sin que le haya ocurrido gastar madera en dichas obras". 